\title{
Orogenic Segmentation and Its Role in Himalayan Mountain Building
}

\author{
Mary Hubbard ${ }^{*}$, Malay Mukul'2, Ananta Prasad Gajurel ${ }^{3}$, Abhijit Ghosh ${ }^{4}$, \\ Vinee Srivastava ${ }^{5}$, Bibek Giri', Neil Seifert ${ }^{1}$ and Manuel M. Mendoza ${ }^{4}$

\begin{abstract}
'Department of Earth Sciences, Montana State University, Bozeman, MT, United States, ${ }^{2}$ Continental Deformation Trichandra Multiple Campus, Tribhuvan University, Kathmandu, Nepal, ${ }^{4}$ Department of Earth Sciences, University of California, Riverside, Riverside, CA, United States, ${ }^{5}$ Department of Earth and Environmental Sciences, Indian Institute of Science Education and Research, Bhopal, India
\end{abstract} \\ Laboratory, Department of Earth Sciences, Indian Institute of Technology Bombay, Mumbai, India, ${ }^{3}$ Department of Geology,
}

The continental collision process has made a large contribution to continental growth and reconfiguration of cratons throughout Earth history. Many of the mountain belts present today are the product of continental collision such as the Appalachians, the Alps, the Cordillera, the Himalaya, the Zagros, and the Papuan Fold and Thrust Belt. Though collisional mountain belts are generally elongate and laterally continuous, close

OPEN ACCESS

Edited by: György Hetényi, University of Lausanne, Switzerland

Reviewed by: R. Jayangonda Perumal, Wadia Institute of Himalayan Geology,

India

Rodolphe Cattin

Université de Montpellier, France

*Correspondence:

Mary Hubbard

mary.hubbard@montana.edu

Specialty section:

This article was submitted to Structural Geology and Tectonics, a section of the journal

Frontiers in Earth Science

Received: 14 December 2020

Accepted: 29 March 2021

Published: 23 April 2021

Citation:

Hubbard M, Mukul M, Gajurel AP,

Ghosh A, Srivastava V, Giri $B$ Seifert N and Mendoza MM (2021) Orogenic Segmentation and Its Role in Himalayan Mountain Building.

Front. Earth Sci. 9:641666.

doi: 10.3389/feart.2021.641666 inspection reveals disruptions and variations in thrust geometry and kinematics along the strike of the range. These lateral variations typically coincide with cross structures and have been documented in thrust fault systems with a variety of geometries and kinematic interpretations. In the Himalaya, cross faults provide segment boundaries that, in some cases separate zones of differing thrust geometry and may even localize microseismicity or limit areas of active seismicity on adjacent thrust systems. By compiling data on structural segmentation along the length of the Himalayan range, we find lateral variations at all levels within the Himalaya. Along the Gish fault of the eastern Indian Himalaya, there is evidence in the foreland for changes in thrust-belt geometry across the fault. The Gish, the Ganga, and the Yamuna faults all mark boundaries of salients and recesses at the mountain front. The Benkar fault in the Greater Himalayan sequence of eastern Nepal exhibits a brittle-ductile style of deformation with fabric that crosscuts the older thrust-sense foliation. Microseismicity data from several regions in Nepal shows linear, northeast-striking clusters of epicenters sub-parallel to cross faults. The map pattern of aftershock data from the 2015 Nepal earthquakes has an abrupt northeasttrending termination on its eastern side suggesting the presence of a structure of that orientation that limited slip. The orientations of the recognized cross faults and seismic patterns also align with the extensional zones to the north on the Tibetan Plateau and the Indian basement structures to the south. Results from multiple studies are consistent with a link between cross faults and either of these structural trends to the north or south and suggest that cross faults may play a role in segmenting deformation style and seismic activity along the length of the Himalaya.

Keywords: Himalaya, segmentation, Nepal, India, transverse zone, cross fault 


\section{INTRODUCTION}

The continental collision process has been responsible for the mountain building of many modern mountain ranges as well as a number of those for which we only see the remnants. The Appalachians, the Alps, the Cordillera, the Zagros, and the Papuan Fold and Thrust Belt are a few examples where continental collision or terrane accretion has resulted in mountain belts (Johnson and Harley, 2012). In many of these orogens we can trace thrust fault systems for large distances, however, in most cases there are disruptions and variations in thrust geometry and kinematics along the strike of the range. These lateral variations typically coincide with cross structures and have been documented in thrust fault systems from these mountain belts and other fold and thrust belts with a variety of geometries and kinematic interpretations. In the Alps, the Simplon Line and the Brenner Line are wellknown cross structures that have accommodated range-parallel extension, likely accompanied by range-parallel transcurrent kinematics (Selverstone, 1988; Hubbard and Mancktelow, 1992). In the Appalachians and Papuan Fold and Thrust Belt, cross structures have been interpreted as tear faults or lateral ramps (Stearns, 1955; Mahoney et al., 2017). In western North America, structures such as the Charleston-Nebo Salient or the Helena Salient coincide with pre-existing basement structures (Constenius et al., 2003; Sears, 2016). While it is clear that cross structures have been recognized in other orogens, much of the structural focus of research in the Himalaya has been on range-parallel thrusts and extensional zones. Review of the Himalayan literature reveals that the geology of the Himalaya is most commonly presented in the context of the major, range-parallel faults that separate packages of rock of generally differing metamorphic grade and lithotectonic origin (Hodges, 2000). This structural configuration was recognized early on by Heim and Gansser (1939). Since that time researchers have conducted detailed field work locally and utilized modern analytical methods to further refine our understanding of the location, style of deformation, and timing of movement of these fault zones (e.g., summarized in Hodges, 2000; Yin, 2006; Searle and Treloar, 2019). It is through these detailed studies over a period of more than 50 years, that workers have recognized lateral discontinuities (e.g., Sastri et al., 1971; Dasgupta et al., 1987; Mugnier et al., 1999a). Types of lateral discontinuities include differences in foreland sediment thickness (Duvall et al., 2020); salients and recesses at the mountain front (Mukul, 2010); discontinuous, or offset sedimentary units in the lowest part of the range (Mugnier et al., 1999b); interaction between basement structures and foreland propagating thrusts (Sahoo et al., 2000); lateral variations in duplex geometries (Mitra et al., 2010; DeCelles et al., 2020); presence of shear fabric orthogonal to range (Hubbard et al., 2018); and discontinuous patterns of seismicity and other geophysical data (e.g., Rajaure et al., 2013; Hetényi et al., 2016).

Many types of data now support the concept that deformation may have partitioned through time along these range-parallel structures in the Himalaya (Gahalaut and Arora, 2012; Rajaure et al., 2013; Hetényi et al., 2016; Mugnier et al., 2017;
Bilham, 2019; Mendoza et al., 2019; DeCelles et al., 2020; Duvall et al., 2020). Both geologic and seismic patterns exhibit lateral changes that coincide spatially with the presence of cross-faults (Paul et al., 2015; Hubbard et al., 2016; Srivastava et al., 2018). Historic earthquake records also suggest there may be segment boundaries limiting rupture extent (Hubbard et al., 2016; Bilham, 2019). To date, there is a recognition of the existence of cross structures, but a lack of data regarding how cross-faults relate to contraction along orogen-parallel structures, to lateral heterogeneities in the geology, and to modern seismicity. We present here a review of what has been observed along the range that may help us as we work to understand how deformation has been partitioned in the past and what we may expect in the future as this mountain belt continues its active role as our preeminent collisional orogen.

\section{HIMALAYAN FRAMEWORK}

As the world's highest mountain range and the world's most developed, active, collisional mountain belt, the Himalaya has seen a surge of geoscience research in the past half century. While the general structural and lithotectonic configuration of the Himalaya was worked out early (Heim and Gansser, 1939), recent work has been focused on refining stratigraphic details (e.g., DeCelles et al., 2001), understanding the cooling and exhumation history (reviewed in: Adlakha et al., 2013; Cottle et al., 2015), reconstructing the collisional history (e.g., Orme et al., 2015), and analyzing the seismicity to understand crustal structure in three dimensions (e.g., Mendoza et al., 2019). The Himalayan orogen is the product of the convergence following the collision of the Indian and Eurasian continents. Recent work provides evidence that this collision initiated at 58-61 Ma (DeCelles et al., 2014; Orme et al., 2015). The result of this collisional process in the Himalaya was the southward-directed thrusting of slivers of the leading edge of the Indian continent resulting in a series of range-parallel, dominantly in-sequence thrust faults separating lithotectonic units from successively deeper crustal levels toward the north. From south to north these units include (Figure 1): (1) the Sub-Himalayan zone including deformed Siwalik molassic sedimentary units, hanging wall to the Main Frontal Thrust (MFT); (2) the Lesser Himalayan zone, hanging wall to the Main Boundary Thrust (MBT); and (3) the Greater Himalayan Sequence (GHS), hanging wall to the Main Central Thrust (MCT). The Greater Himalaya is bound to the north by a north dipping normal fault system known as the South Tibetan Detachment System (STDS). South of the Himalaya the Indo-Gangetic Plain is underlain by Precambrian units of the Indian craton (see review in Godin et al., 2018) that are covered by a Gondwanan sedimentary sequence and Quaternary alluvial sediments including those of the Ganga Basin (Veevers and Tewari, 1995; Agarwal et al., 2002). Geophysical evidence suggests that the major thrust faults root in a midcrustal detachment known as the Main Himalayan Thrust (MHT) (Zhao et al., 1993; Avouac, 2003; Nabelek et al., 2009), the southernmost expression of which is the MFT (Pandey et al., 1999). A ramp structure in the MHT has been suggested as the cause of 


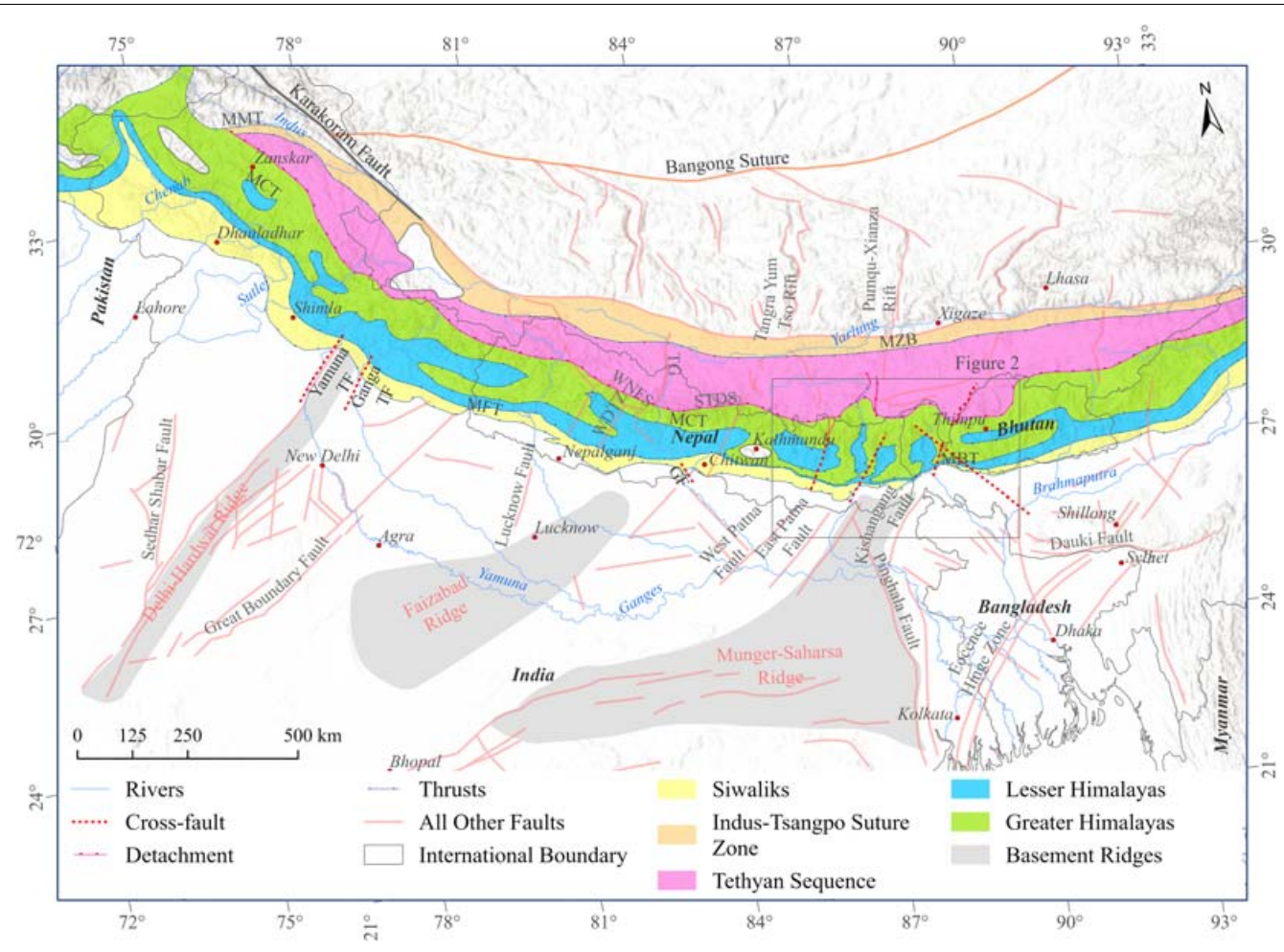

FIGURE 1 | Simplified lithotectonic map of the Himalaya. The heavy, dashed red lines indicate Himalayan cross structures. The brick-colored lines represent extensional structures on the Tibetan Plateau and basement faults on the Indian craton. The light gray shaded areas are basement ridges. GF: Gardi Tear Fault; MBT: Main Boundary Thrust; MCT: Main Central Thrust; MFT: Main Frontal Thrust; STDS: South Tibetan Detachment System; TF: Tear Fault; TG: Thakkhola graben; WNFS: Western Nepal Fault System (source: the Department of Mines and Geology, Nepal; Gansser, 1964; Godin and Harris, 2014; Diehl et al., 2017; Divyadarshini and Singh, 2019; the Geological Survey of India; Sastri et al., 1971; Sahoo et al., 2000; Searle et al., 2003; Jessup et al., 2008; Silver et al., 2015; Seifert, 2019 and compiled by Bibek Giri).

mega-earthquakes as well as the abrupt increase in elevation and interseismic seismicity between the Lesser Himalayan and Greater Himalayan zones (Pandey et al., 1995; Cattin and Avouac, 2000; Nabelek et al., 2009; Elliott et al., 2016).

Timing of in-sequence deformation is thought to generally young to the south, though some recent work has found evidence for younger, out-of-sequence deformation throughout the range (e.g., Mukul et al., 2007; Carosi et al., 2010; Larson and Cottle, 2014; Larson, 2018). Research results also suggest that timing may vary somewhat along the length of the range (Webb et al., 2017). The last few decades have seen debate in the literature about whether movement on the MCT and the STDS were coeval (Beaumont et al., 2004; Hodges, 2006; Kohn, 2008; Searle et al., 2008). While there is evidence that both structures may have been active between $\sim 22$ and $19 \mathrm{Ma}$ (e.g., Hubbard and Harrison, 1989; Burchfiel et al., 1992; Hodges et al., 1992; Kellett et al., 2018), data from several parts of the range suggest that the MCT and other structures within the Greater Himalayan Sequence (GHS) may have been active more recently (Catlos et al., 2002; Montemagni et al., 2019) and the STDS may have initiated as early as $30 \mathrm{Ma}$ and ceased by $19 \mathrm{Ma}$ in some areas (Soucy La Roche et al., 2016) and $12 \mathrm{Ma}$ in others (Godin et al., 2006). The Main Boundary Thrust system is generally less well-exposed than the MCT and constraining its timing has posed a greater challenge. Best estimates are that the MBT deformation initiated at 11-9 Ma and may have continued into the Pliocene (Meigs et al., 1995; DeCelles et al., 1998) with even the possibility of Quaternary displacement (Nakata, 1972; Mukul, 2000; Hossler et al., 2016). DeCelles et al. (2020) propose that the major slip on the MBT is probably younger than $\sim 5 \mathrm{Ma}$ based on clasts with hanging wall lithologies found in units of the footwall Siwalik Group. It has been recognized along most parts of the range that the Lesser Himalaya has been deformed as a duplex structure, so there was significant shortening taken up between the MCT and the MBT possibly in a similar time frame as the estimates for MBT deformation (Huyghe et al., 2001; Robinson et al., 2001; Szulc et al., 2006; Bhattacharyya and Mitra, 2009; Mitra et al., 2010). The Main Frontal Thrust system is neotectonically active as the southernmost expression of thrust deformation of the Himalaya (Mukul et al., 2007; Srivastava et al., 2016; DeCelles et al., 2020). This structural zone is thought to have been active since the Pliocene based on the cooling ages and depositional ages of the deformed Siwalik group in the hanging wall (Ojha et al., 2000; DeCelles et al., 2020).

Over the years a number of controversies have emerged such as how to define the MCT, the origin of klippen of high-grade lithologies in the Lesser Himalaya, and the amount of shortening accommodated by duplex structures in the Lesser Himalaya 
(Hodges, 2006; Searle et al., 2008; Soucy La Roche et al., 2018; DeCelles et al., 2020). In some cases, differences in interpretations may be rooted in structural variations that we are now recognizing along the range (Yin, 2006). There is evidence that lateral heterogeneities exist in all of the tectonic units from the Ganges plain south of the MFT to the Greater Himalayan sequence along the northern edge of the orogen. In some cases, lateral changes are bound by recognized cross structures, but in other cases a lateral change is recognized with either a broad transitional zone or without sufficient field data to pinpoint a specific structure that delineates the change (e.g., Mugnier et al., 1999a; Srivastava and Mukul, 2020).

\section{LATERAL HETEROGENEITIES AND EVIDENCE FOR CROSS FAULTS}

\section{Indo-Gangetic Plain}

Recognition of geologic features on the Indo-Gangetic Plain that are oriented perpendicular to the trend of the Himalaya goes back to early geological and geophysical studies (Burrard, 1915; Oldham, 1917; Sastri et al., 1971; Rao, 1973; Valdiya, 1976). The great thickness of sediments in the Himalayan foreland, including the Ganga basin, was recognized as early as the time of Suess (1904). Burrard (1915) and Oldham (1917) presented differing interpretations of the presence of the sedimentary sequence based on early geophysical measurements, but it was really during the time of extensive oil and gas-related exploration that geophysical results and drilling revealed transverse structures underlying the foreland sedimentary basin (Sastri et al., 1971; Rao, 1973; Raiverman et al., 1983). Presence of these structures is confirmed in the seismic data (e.g., Dasgupta et al., 2000). Sastri et al. (1971) summarize the basement structure of the Ganga basin as a series of NE-striking basement ridges separated by basement depressions (Figure 1). In the east, the Munger-Saharsa ridge lies between the Kishanganj fault and the East Patna fault and has 3,000 m of overlying Neogene sediments. To the west, the depression between the Munger-Saharsa ridge and the Faizabad ridge has up to $6,000 \mathrm{~m}$ of sediment including Vindhyan (1.6-1.7 $\mathrm{Ga})$, Paleogene, and Neogene units suggesting that the differential sedimentation and therefore the NE-striking ridge structures pre-date the India-Asia collision. There is also evidence now that faults that bound these basement ridge structures, may also bound blind thrust propagations off of the Main Himalayan Thrust under the modern foreland (Duvall et al., 2020). Duvall et al. (2020) used data from a grid of industry seismic lines from the foreland region in eastern Nepal to map NE-striking strike-slip faults, several of which bound the Munger-Saharsa ridge. These faults penetrate from the basement up through the Quaternary Upper Siwalik units. Between two of the easternmost of their studied faults there is a blind thrust in a region known as the Bhadrapur High (Figure 2), with an estimated $\sim 80-110 \mathrm{~m}$ of slip. They suggest that this thrust fault may be the early stages of the formation of a range-front salient. The configuration of cross faults bounding a thrust segment is consistent with the idea that cross faults may play a role in limiting lateral thrust propagation. Based on the seismic imaging data, Duvall et al. (2020) suggest that these cross faults, that originate in the basement, may continue northward into the Himalaya as suggested earlier by Mukul (2010); Godin and Harris (2014), Godin et al. (2018), and Soucy La Roche and Godin (2019).

\section{Sub-Himalayan Zone}

The availability of high-resolution topographic data and satellite imagery visually illuminates the lateral heterogeneities in the southern mountain front of the Himalaya. Perhaps most notable are the number of salients and reentrants/recesses along the length of the range (Yeats and Lillie, 1991; Powers et al., 1998; Mukul, 2010). The dun valleys of the Sub-Himalayan zone are enclosed valleys often bound by fault-related folds of the Siwalik Group. These valleys also mark diachronous and contrasting geomorphic expressions of deformation along the range (Kimura, 1999).

In the northwestern Indian Himalaya, there have been several efforts to quantify amounts of shortening and shortening rates in the Sub-Himalayan zone (Powers et al., 1998; Dubey et al., 2001; Srivastava et al., 2018). Dubey et al. (2001) balance multiple crosssections in the area between Dhauladhar Range and the Shimla (Figure 1) and they found significant variability in amounts of shortening from $\sim 22$ to $71 \%$ along the range. They conclude that this variability may actually be a result of different approaches to cross section balancing. Dubey (1997) conducted analog modeling of an oblique ramp in a convergent setting and makes a connection to the geometry of reentrants in the northwestern Indian Himalaya.

In the region of the Indian Himalaya where the Yamuna and Ganga rivers emerge, the range front is visibly offset. Sahoo et al. (2000) processed satellite imagery of this area and make an interpretation that tear faults were responsible for this offset (Figure 1). Further mapping in that area, which overlies the Delhi-Hardwar basement ridge, has confirmed the presence of cross faults at the recess boundaries (Sahoo et al., 2000; Srivastava et al., 2018). Geologic mapping in deformed molasse and foreland sediment, known as the Siwaliks, of western Nepal demonstrated the need for an orthogonal transfer zone where the structural nature of the range front thrust systems changed abruptly along strike (Mugnier et al., 1999a,b). This transfer zone marks the western boundary of several dun structures in the Sub-Himalayan zone and has been referred to as the West Dang transfer zone, a possible east-dipping lateral ramp (Mugnier et al., 1999a) that may continue northward into the Lesser Himalaya (see section "Discussion" below).

In Central Nepal, in the region of the Chitwan Dun, the range front topography is also irregular. Divyadarshini and Singh (2019) mapped six strands of the MFT at this site, some of which remain distinct for short distances, and others of which merge with each other. These workers have also identified a NNWstriking tear fault above the MFT they call the Gardi Tear Fault.

Farther east, in eastern Nepal and Sikkim, two other cross faults have been recognized at salient-recess boundaries along the range front (Figure 2), the Kosi fault in eastern Nepal along the Indian border, and the Gish fault in Sikkim (Mukul, 2010; Srivastava et al., 2017; Mukul et al., 2018). The Kosi fault was recently identified by Mukul et al. (2018) as a possible cross 


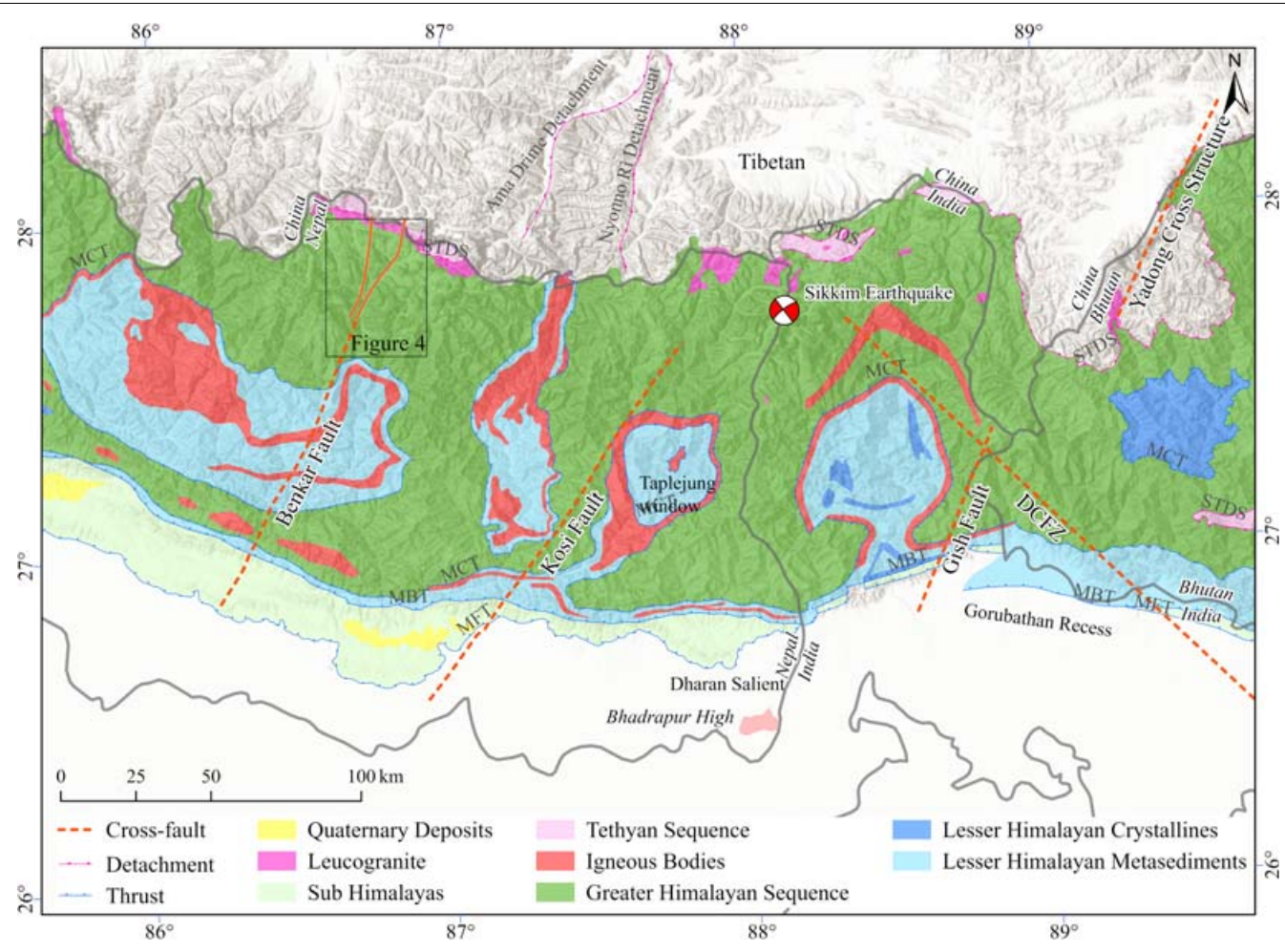

FIGURE 2 | Simplified geologic map of eastern Nepal, India, and western Bhutan. The red dashed lines are the approximate locations of the Benkar, Kosi, Gish, and Dhubri-Chungthang cross faults. The solid yellow lines are the bounds of the Benkar fault zone that have been mapped in the Greater Himalayan Sequence (Seifert, 2019). Sikkim $M_{w}$ 6.9, 2011 earthquake fault plane solution from Paul et al. (2015). DCFZ: Dhubri-Chungthang Fault Zone; MBT: Main Boundary Thrust; MCT: Main Central Thrust; MFT: Main Frontal Thrust; STDS: South Tibetan Detachment System; [Map data from the Department of Mines and Geology, Nepal, the Geological Survey of India, and Greenwood et al. (2016). Map compiled by Bibek Giri].

fault marking the western boundary of the Dharan salient. This structure aligns with the western boundary of the MungerSaharsa basement ridge structure in the foreland. Though it has not yet been mapped to the north, its projection may align with the Pumqu Xianza rift of the hinterland (Yin and Taylor, 2011). Microseismicity patterns in the area outline a concentration of events that follows the strike of the Kosi fault suggesting that the structure is active (Pandey et al., 1999; Monsalve et al., 2006; De La Torre et al., 2007). The strike of the fault also aligns with the western edge of the Taplejung window (Figure 2) that offsets the MCT in an apparent sinistral sense (Upreti et al., 2003).

The Gish fault has been mapped from the range front into the lesser Himalaya, and the GHS. This fault was first identified in West Bengal/Sikkim region of India (Mukul et al., 2009), where it forms the boundary between the Dharan salient and the Gorubathan recess. Following its recognition, continued research has included geomorphic, structural, and geodetic analysis of the region along, and adjacent to this fault (Srivastava et al., 2017; Mukul et al., 2018; Srivastava and Mukul, 2020). The structural and geomorphic research has focused on the range front of the Himalaya and has documented very different structural styles on either side of the Gish fault, with the Ramgarh Thrust (structurally between the MCT and the MBT) marking the range front in the Gorubathan recess (Matin and Mukul, 2010) and a series of blind thrusts toward the foreland, whereas the Dharan salient has multiple exposed thrusts south of the Ramgarh Thrust. The Ramgarh Thrust is displaced in a sinistral sense across the Gish fault. Deformation style of the Munsiari thrust sheet (structurally between the Ramgarh Thrust and the MCT) differs across the Gish fault and has fold features that are affected by the Gish fault (Matin and Mukul, 2020). Mukul (2010) has traced this fault across the MCT, though the structure has not been mapped in detail in the area of the MCT or further north. The Gish fault aligns with the Kishanganj fault on the eastern edge of the Munger-Saharsa ridge of the Indian basement (Figure 1). This region has had a number of strike-slip seismic events ( $\mathrm{Ni}$ and Barazangi, 1984; Paul et al., 2015).

\section{The Lesser Himalaya}

Along-strike variations have been recognized in the Lesser Himalayan zone from topographic data, seismic data, and from cooling history data, suggesting segmentation in tectonic processes (Harvey et al., 2015; van der Beek et al., 2016; Soucy La Roche and Godin, 2019). Hodges et al. (2001) described the topography in the Himalaya along NS transects as having multiple physiographic transitions (PT1, PT2, and PT3). PT2 defined by these authors, is an elevation transition from the highest peaks of the Himalaya, typically consisting of the Greater Himalayan Sequence units, to the region of lower elevations to the south in the Lesser Himalaya. In western Nepal, between the 
longitudes of $82.5^{\circ} \mathrm{E}$ and $81^{\circ} \mathrm{E}$, Harvey et al. (2015) show that the PT2 transition bifurcates around an area of relatively low topographic relief. They interpret the PT2S (south) and the PT2N (north) as locations that transition to areas of faster rock uplift and they further document these transitions with the locations of knick points in river channels. Harvey et al. (2015) also present the seismic data from Ader et al. (2012) that shows a broadening of the microseismicity pattern in the area west of $\sim 82^{\circ} \mathrm{E}$ and suggest that the ramp in the MHT turns northwestward at that point and that additional duplexing may be occurring at depth in the Lesser Himalayan region. Several other studies have provided additional evidence for a lateral change at $\sim 82^{\circ}$ E longitude. van der Beek et al. (2016) compared stream power and apatite fission track ages (AFT) from a N-S transect west of $82^{\circ} \mathrm{E}$ and a similar transect in central Nepal. They, too, concluded that there is a likely structural change in the ramp geometry of the MHT, possibly involving a lateral ramp crossing the strike of the range. These changes align with the West Dang Transfer Zone proposed by Mugnier et al. (1999a) based on their work in the Sub-Himalaya to the south. DeCelles et al. (2020) documents changes in duplexing geometry along strike in this zone.

There is further evidence for lateral changes in the MHT in western Nepal that comes from the differences in peak metamorphic temperatures obtained by the Karnali and Jajarkot klippen as well as the timing of metamorphism (Soucy La Roche and Godin, 2019). Exhumation occurred at 20-15 Ma for the Karnali klippe and at 20-25 Ma for the Jajarkot klippe (Soucy La Roche et al., 2019). Soucy La Roche and Godin (2019) interpret these T-t differences to represent a difference in the depth to the MHT of about $13 \mathrm{~km}$ and suggest that this exhumation difference reflects segmentation going back to at least the Oligocene. They further interpret re-activation of the Lucknow fault on the west side of the Faizabad ridge to have created a tear fault in the overlying units, thus offsetting the MHT.

The Lesser Himalayan zone is typically characterized along the length of the range as a duplex structure of metasedimentary units from the Kumaon region of India, across Nepal and Sikkim, and into Bhutan (Srivastava and Mitra, 1994; DeCelles et al., 1998; McQuarrie et al., 2008; Bhattacharyya and Mitra, 2009). Structural cross sections from each of these regions reveal significant variations in duplex geometry (e.g., Yin, 2006). While some of these variations may be differences in interpretation, there are clear differences in thickness of the duplex systems, fold geometry, numbers of horses, and shortening estimates in each section (Hauck et al., 1998; DeCelles et al., 2001, 2020; Johnson et al., 2001; Grujic et al., 2002; Mitra et al., 2010; Long et al., 2011). Some of these transitions in style may be gradual, but it has also been noted that duplex or underplating geometry can change across cross faults, tear faults, oblique or lateral ramps (Dubey et al., 2001; Yin, 2006; Harvey et al., 2015).

\section{The Greater Himalaya}

Much of the discussion in the literature pertaining to lateral variations in the Greater Himalaya has focused on differences in cooling histories, exhumation rates, and topographic profiles, in some cases extrapolated from the Lesser Himalaya (e.g., Duncan et al., 2003; Robert et al., 2011; Eugster et al., 2018). Further discussions have also included variations in the role of climate on erosion and the differences in the presence or absence of discontinuities within the Greater Himalayan zone (Carosi et al., 2010; Larson and Cottle, 2014). Perhaps one of the most obvious examples of lateral variation is in the Greater Himalayan klippen and Lesser Himalayan windows as seen in map pattern (Figure 1; Gansser, 1964; Searle et al., 2008; Thiede et al., 2017). These map pattern variations are largely attributed to variations in the geometries of the Lesser Himalayan duplexing and variations in the presence, absence, or position of a ramp in the MHT (Hodges, 2000; Robinson et al., 2001; Deeken et al., 2011; Kohn, 2014).

In the northwest Himalaya, there are a number of changes that occur in Greater Himalayan cooling ages and inferred exhumation rates between the Sutlej River valley and the Zanskar region (Eugster et al., 2018). Eugster et al. (2018) used lowtemperature thermochronology to look at cooling histories for three cross-strike transects from the Sutlej river to the Dhauladhar Range. Their two southeasternmost transects show younger ages in the Greater Himalayan section and therefore suggest a more recent and more rapid exhumation than the Dhauladhar section to the northwest. They also note that there is a change in the topography toward the northwest with an elimination of the PT2 topographic change. A number of factors have been suggested as causes for changes in exhumation history in the northwestern Himalaya such as an increase in the obliquity of convergence (Thakur et al., 2014), a decrease in rainfall at the higher elevations than in the central part of the range (Bookhagen and Burbank, 2006), differences in pre-collisional sediment thickness (Rajendra Prasad et al., 2011) and the reactivation of inherited basement structures (Arora et al., 2012). The changes in obliquity of convergence or rainfall would likely produce broad areas of change whereas changes in sediment thickness or basement fault reactivation could create the more abrupt changes in deformation style, topography, or exhumation that are observed (Eugster et al., 2018).

Thakur et al. (2019) describe the Ropar-Manali lineament, first identified by Virdi (1979), as a dextral strike-slip cross fault that coincides with the segmentation suggested by Hetényi et al. (2016) based on arc-parallel gravity anomalies. In the area of the southern Sutlej River, near Shimla, geologic map pattern suggests a ramp in the MCT such that to the northwest, the MCT ramps up-section to the point that the STDS and the MCT merge (Thakur, 1998; Yin, 2006). This ramp has been referred to as the Mandi ramp (Yin, 2006) and it coincides with the Ropar-Manali lineament described in Thakur et al. (2019).

Low temperature thermochronology coupled with kinematic modeling in central Nepal supports the presence of a ramp in the MHT as is imaged in seismic data (Robert et al., 2011; Elliott et al., 2016). Young apatite fission track ages (AFT) in the Greater Himalaya ( $<3 \mathrm{Ma}$ ) with older ages in the Lesser Himalaya in central and western Nepal contrast with the age pattern in Bhutan which consists of older AFT ages ( $>3 \mathrm{Ma}$ ) in the Greater Himalaya and younger ages (3-5 Ma) in the Lesser Himalaya. Robert et al. (2011) used this data in thermal kinematic modeling and concluded that the MHT ramp that is present in central Nepal is likely absent in Bhutan. These authors also suggest that the topographic differences that result from variations in MHT 
geometry further impact the location of higher precipitation and therefore higher erosion rates. Thermochronology data and kinematic modeling of an east and west transect in Bhutan (Coutand et al., 2014) suggests that the MHT ramp geometry changes from west to east and that exhumation rates may decrease to the east. Topographic variations all along the range have also been characterized by river channel steepness $\left(k_{s n}\right)$ in the Greater Himalaya with high values of $\mathrm{k}_{s n}$ relating to strain accumulation (Cannon et al., 2018). The variability of $\mathrm{k}_{s n}$ displays a segmentation along the length of the range. Cannon et al. (2018) suggest that this variability coupled with several other parameters may correspond with variability in the occurrence of major earthquakes along the MHT.

While lateral variations along the Greater Himalaya are clearly expressed in topographic profiles, differences in cooling/exhumation histories, and the presence or absence of leucogranites (Weinberg, 2016), there are limited locations where individual structures have been identified in the field that may be linked to the lateral variations or the segmentation of the range. In eastern Nepal, a fault was recently recognized in the Greater Himalaya that could be related to the segmentation process. The Benkar fault zone was first recognized in the Dudh Kosi valley north of the village of Lukla (Hubbard et al., 2018) and was subsequently mapped across the Greater Himalaya to the north (Figure 3; Seifert, 2019; Seifert et al., 2019). Key outcomes from this work were that the NE-striking deformation zone is $\sim 3-11 \mathrm{~km}$ wide with the widening occurring to the north where it bifurcates around leucogranitic exposures (Figure 4). The deformation is brittle-ductile with much of the slip having occurred on sillimanite-rich layers. Kinematics are fairly consistently right-lateral, normal on a SE-dipping plane. Mapping has not been completed to the north of the Everest basecamp area or to the south of Lukla. To the north the structure may connect with the NW-striking Tangra Yum Co-Kung Co rift system in the southern Tibetan Plateau region (Maheo et al., 2007). To the south there is topographic evidence for a continuation of the Benkar fault down to the Gangetic plain. This topographic feature aligns with the Motihari-Everest transverse fault suggested by lineament mapping from Satellite images (Dasgupta et al., 1987). The Benkar zone may also align with the West Patna fault on the Indo-Gangetic plain. Timing of displacement along the Benkar fault is unknown, though it is younger than the leucogranites. Preliminary $40 \mathrm{Ar} / 39 \mathrm{Ar}$ dating of muscovite separates from three samples along an EW transect indicates that at least some of the movement is younger than 12 Ma (Seifert et al., 2019).

\section{SEGMENTATION AND SEISMICITY}

Historic earthquake data shows the episodic and spatially restricted nature of major thrust fault rupture along the length of the Himalaya (Ambraseys and Douglas, 2004; Bilham, 2004, 2019). Wesnousky et al. (2019) recently presented new trench data that when coupled with earlier trench work supports the possible simultaneous rupture of a $250 \mathrm{~km}$ long segment of the Main Frontal Thrust (MFT) at $\sim 1,100$ CE.
Le Roux-Mallouf et al. (2020) also trenched an area along the MFT in western Bhutan and from evidence of multiple large rupture events interpreted a recurrence interval for great earthquakes of about 550 year. The spatial arrangement of rupture events supports the possibility of segment boundaries that may limit the lateral rupture propagation (Hubbard et al., 2016; Bilham, 2019), though details of most historic events remain poorly known. Aftershock data from the 2015 Gorkha earthquake (Karplus et al., 2020) shows a pattern of seismicity (Figure 5) that terminates to the east along an abrupt NE-SW trend (Mendoza et al., 2019). When projected to the Earth's surface, this termination coincides with the Gauri Shankar lineament (Dasgupta et al., 1987) and is similar in orientation to the traces of cross faults that have been mapped in the SubHimalaya and the Greater Himalaya elsewhere in the range (Hubbard et al., 2018; Srivastava and Mukul, 2020). Imaging the third dimension of this data on the western side also led Mendoza et al. (2019) to propose a change in structural style based on the change in the patterns of aftershocks. This structural transition to a duplex geometry also occurs along a NE trend. Seismic activity also shows strong lateral variations with a highly active eastern section and low activity to the west of the rupture area. In several areas of the Himalaya, microseismic events align along linear, NE-striking zones (Rajaure et al., 2013) suggesting the presence of cross faults that are active, even if the displacement along them is small. Hoste-Colomer et al. (2017) saw further evidence for cross faults or tear faults in seismic data associated with a 1997 event north of Kathmandu and they comment on similar seismic swarms in eastern and western Nepal.

In 2011, Sikkim experienced an Mw 6.9 earthquake. Using a moment tensor inversion technique, Paul et al. (2015) determined that the main shock origination was at $\sim 53 \mathrm{~km}$ depth and that the earthquake occurred along a NW-striking, near vertical fault and that displacement was dextral along that surface. Aftershocks occurred to the SE of the main shock at depths from 12 to $50 \mathrm{~km}$. These results suggest that much of the deformation was occurring within the subducting Indian plate beneath the MHT. There is evidence from additional earthquake data that the 2011 Sikkim event occurred on the Dhubri-Chungthang fault zone that continues southeastward to the western edge of the Shillong Plateau (Diehl et al., 2017). Further east, in Bhutan, many of the earthquakes from the last century have also had strike-slip displacement on steep fault planes and have occurred at depths ranging from $\sim 13$ to $68 \mathrm{~km}$ (Drukpa et al., 2006; Diehl et al., 2017).

In recent years, abundant geodetic data along the Himalaya has led to studies of interseismic coupling (Ader et al., 2012; Stevens and Avouac, 2015; Marechal et al., 2016; Dal Zilio et al., 2020). Ader et al. (2012) and Stevens and Avouac (2016) used data from all along the range and conclude that there is interseismic coupling across the entire length of the range over a $100 \mathrm{~km}$ width and that segmentation is not visible in their data. Marechal et al. (2016) used a higher resolution geodetic data set in the area of Bhutan and found that though there was some amount of interseismic coupling along the length of Bhutan, there was lateral variation in the width of the coupled zone. In addition, 


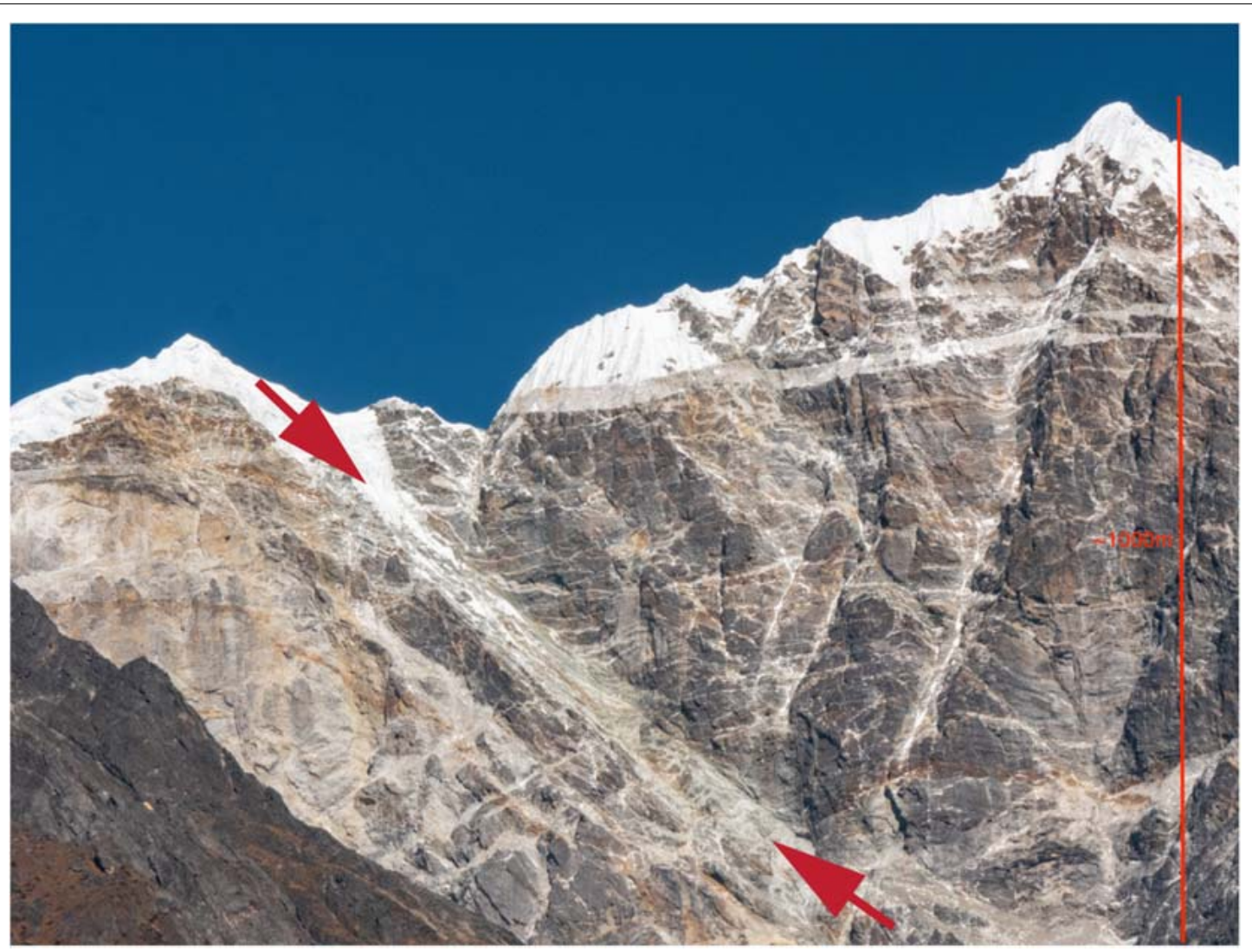

FIGURE 3 | Photograph showing strand of Benkar Fault zone. The view is looking north at the west ridge of Taboche (see location in Figure 4), a peak in the mapped portion of the Benkar Fault zone, in the Khumbu region of Nepal. Red arrows show a zone of shearing to the right (east) of the leucogranite exposure. The vertical profile in this photo is $\sim 1,100 \mathrm{~m}$. This zone has apparent normal displacement within the NE-striking, Benkar Fault zone that has overall dextral, normal sense of shear (photo by Mary Hubbard).

protracted dynamic triggering in the Central Himalaya indicates that slow slip may play a role in interseismic deformation, stress loading and its lateral variation (Mendoza et al., 2016). Dal Zilio et al. (2020) also found lateral heterogeneity in the interseismic coupling and more specifically, found that regions of high interseismic coupling separated by shorter regions of lower coupling, that are aligned with structures in the Indian basement and that create segment boundaries. These segment boundaries also bound the regions of large earthquake rupture in the last millennium, though Mugnier et al. (2017) suggest that segment barriers may be penetrated during the largest earthquake events.

\section{DISCUSSION}

Geologic and geophysical data collected over the past century clearly shows that while much of the Himalaya can be characterized by a continuous series of range-parallel thrust faults, there are also important lateral variations in the architecture of the range. A number of these variations can be tied to specific transverse or cross structures, leading to segmentation of the range. Important questions that come from this recognition of segmentation include the more academic question of what has caused the segmentation and the more applied question of how does the segmentation impact seismicity in terms of fault rupture area and size of earthquake events. We recognize these questions may not be mutually exclusive and the true answers to these questions will require continued data collection, both in the field and in the laboratory, and from multiple disciplines across different space- and time-scales.

To understand possible causes of segmentation, it is useful to look at other collisional mountain belts that also display features of segmentation including cross structures. In some cases, the cross structures are identified as tear faults or lateral ramps (Appalachians and the Papuan Fold and Thrust belt) and in other cases there are transverse extensional structures (Alps). In the Himalayan example, one of the primary explanations for segmentation has been variation in the geometry of the MHT and possibly related variations in duplex geometry in the Lesser Himalaya (e.g., Ader et al., 2012; van der Beek et al., 2016; Mendoza et al., 2019). Geophysical data from the 2015 Gorkha earthquake in Nepal supports these explanations. As to why the MHT and/or duplexing geometries change along the strike of the range, there have been several explanations. Mugnier and Huyghe (2006) note the role of lateral variations 


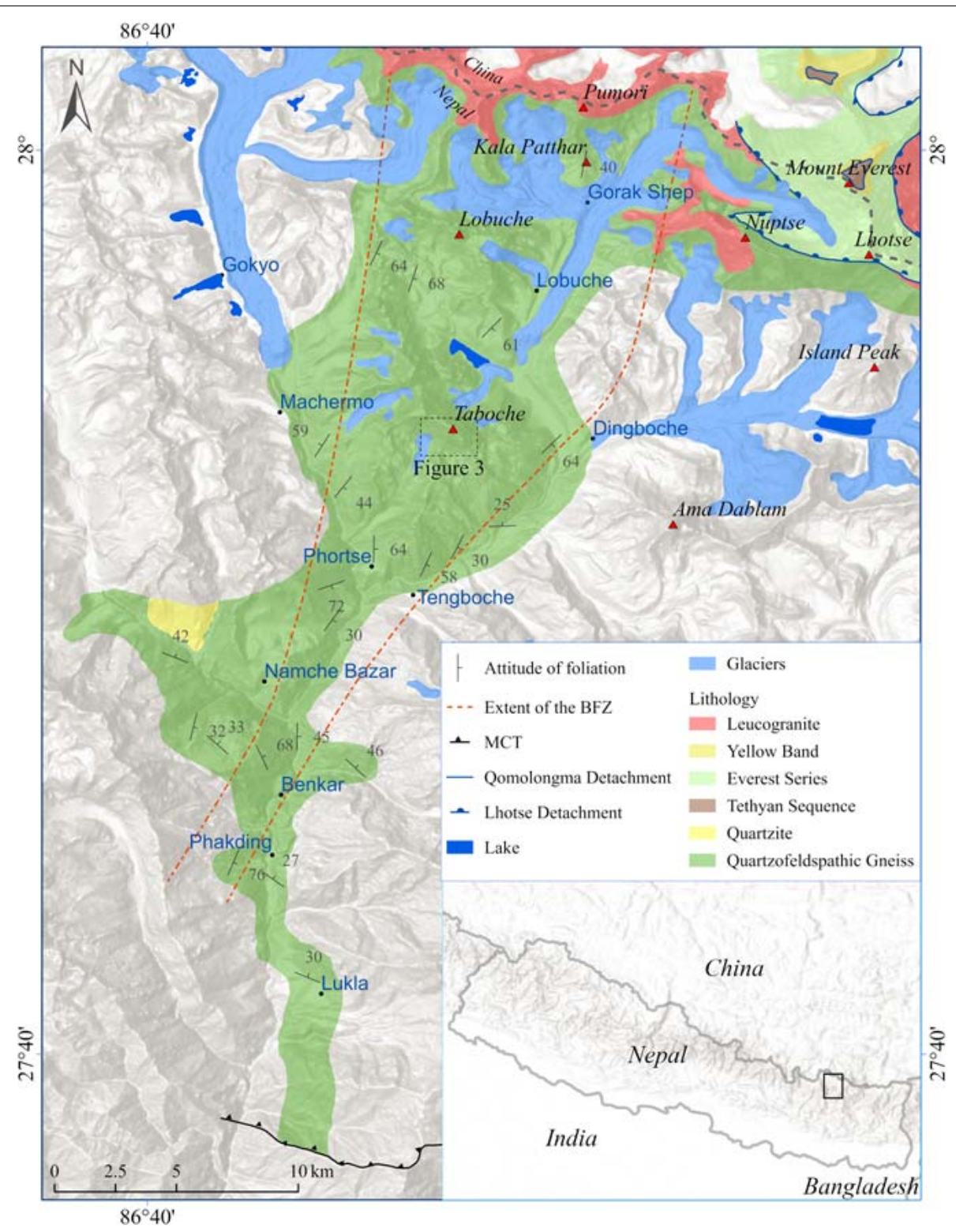

FIGURE 4 | Simplified geologic map of the northern Benkar fault zone. The dotted lines outline the region of non-penetrative, NE-striking shear fabric of the Benkar Fault zone. Kinematics on this shearing are dextral, normal. MCT: Main Central Thrust (after: Seifert, 2019).

in sediment thickness of the Ganga basin in partitioning the basin. These lateral variations are largely controlled by basement structures on the Indian craton. Based on similar orientations and adjacent locations of Indian basement faults and transverse faults in the Lesser Himalaya, Valdiya (1976) proposed that basement faults influenced the development and position of cross faults in the Himalaya. Godin et al. (2018) suggest that basement faults have influenced the lateral changes in structures within the Himalaya, and that they also may have influenced the locations of the NS-striking grabens on the Tibetan plateau. It remains unclear whether structures that are more than $50 \mathrm{~km}$ below the Tibetan upper crust could have influenced the location of the graben structures we see today. Future mapping of cross-faults withing the Himalaya may ultimately help us to understand these possible connections. The NE-striking basement structures are imaged in the foreland on seismic profiles (Duvall et al., 2020) and are shown to penetrate from the basement into the overlying sedimentary cover. Earthquake data from events within the Himalaya show strike-slip kinematics and occur down to depths of 50-60 km supporting the idea that the Indian plate basement faults continue to be active under the major Himalayan thrust faults (Paul et al., 2015). This earthquake data implies that at least some of the cross faults or segment boundaries in the Himalaya are tied to the basement structures and are not just tear faults in the hanging wall of the thrusts. 
While historic earthquake data from the Himalaya has shown us that major events have been localized temporally and spatially in segments of the range (Bilham et al., 2001; Bilham, 2019), earthquake data from the 2015 Gorkha earthquake in central Nepal has provided a data set that reveals how slip was distributed in three dimensions within a crustal segment of the range (Elliott et al., 2016; Hubbard et al., 2016; Mendoza et al., 2019). The fact that the eastern edge of aftershock data ends abruptly along a NE-trending lineament (Figure 5) and that this lineament has been identified as a cross-structure (Mugnier et al., 2017) suggests that cross-structures may play a role in limiting lateral propagation of rupture area and therefore earthquake magnitude (Dowrick and Rhoades, 2004). To the west of Kathmandu there is another transition that occurs about a broad NE-striking zone where the activity of aftershock events shifts from a strongly clustered northern band to a more diffuse band across a $>50 \mathrm{~km}$ wide zone (Mendoza et al., 2019). Maps of microseismicity across the Himalaya also show that there have been concentrations of events along transverse structures (e.g., Figure 6; Rajaure et al., 2013) suggesting that crossfaults could also be capable of slip events like in the 2011 Sikkim earthquake (Paul et al., 2015). Dal Zilio et al. (2021) point out the important role of timescales when looking at the connection between seismicity and segmentation. Whether or not cross fault slip events can generate great earthquakes, or even ameliorate the major Himalayan seismic hazard related to slip along the Main Himalayan thrust, is an important question (Mukul et al., 2018).

The alignment of seismic data with the Indian plate basement structures and the fact that earthquake events with transverse kinematics occur at depths well below the major thrust detachments in the Himalaya, is strong evidence that pre-existing basement structures on the subducting Indian plate are controlling at least some of the segmentation in the mountain building process. Other examples of subducting structures controlling over-riding plate deformation can be seen in oceanic subduction settings. Left lateral strike-slip faults on the continental margin of Oregon and Washington are parallel to, and have been linked to, structures on the subducting Juan de Fuca plate (Goldfinger et al., 1997). A similar scenario has been recognized in NW Sumatra near the site of the 2004 earthquake where N-S striking fracture zone fabric on the subducting plate is suggested to have created N-S striking faults in the overlying accretionary prism (Graindorge et al., 2008). These faults bound

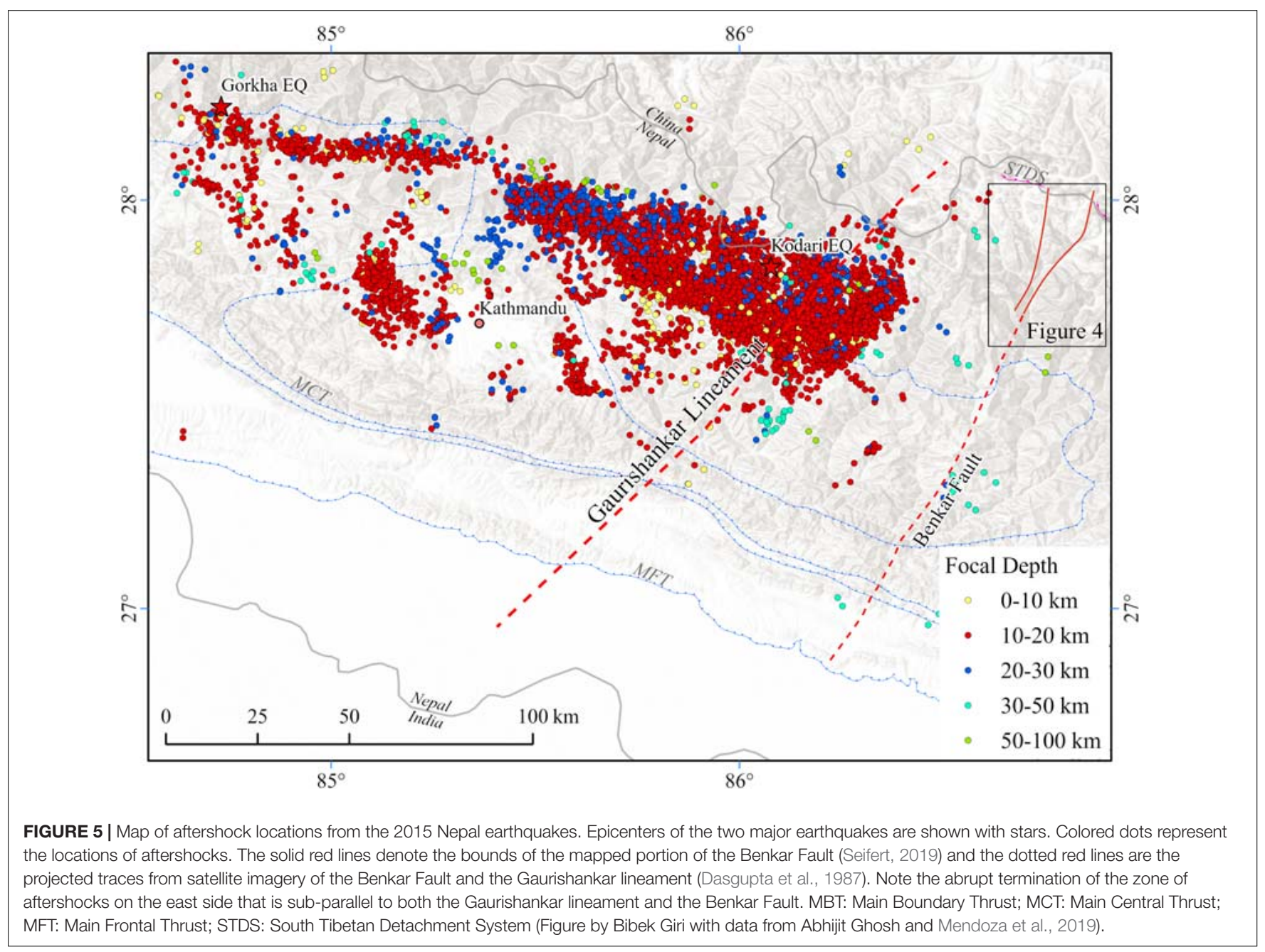




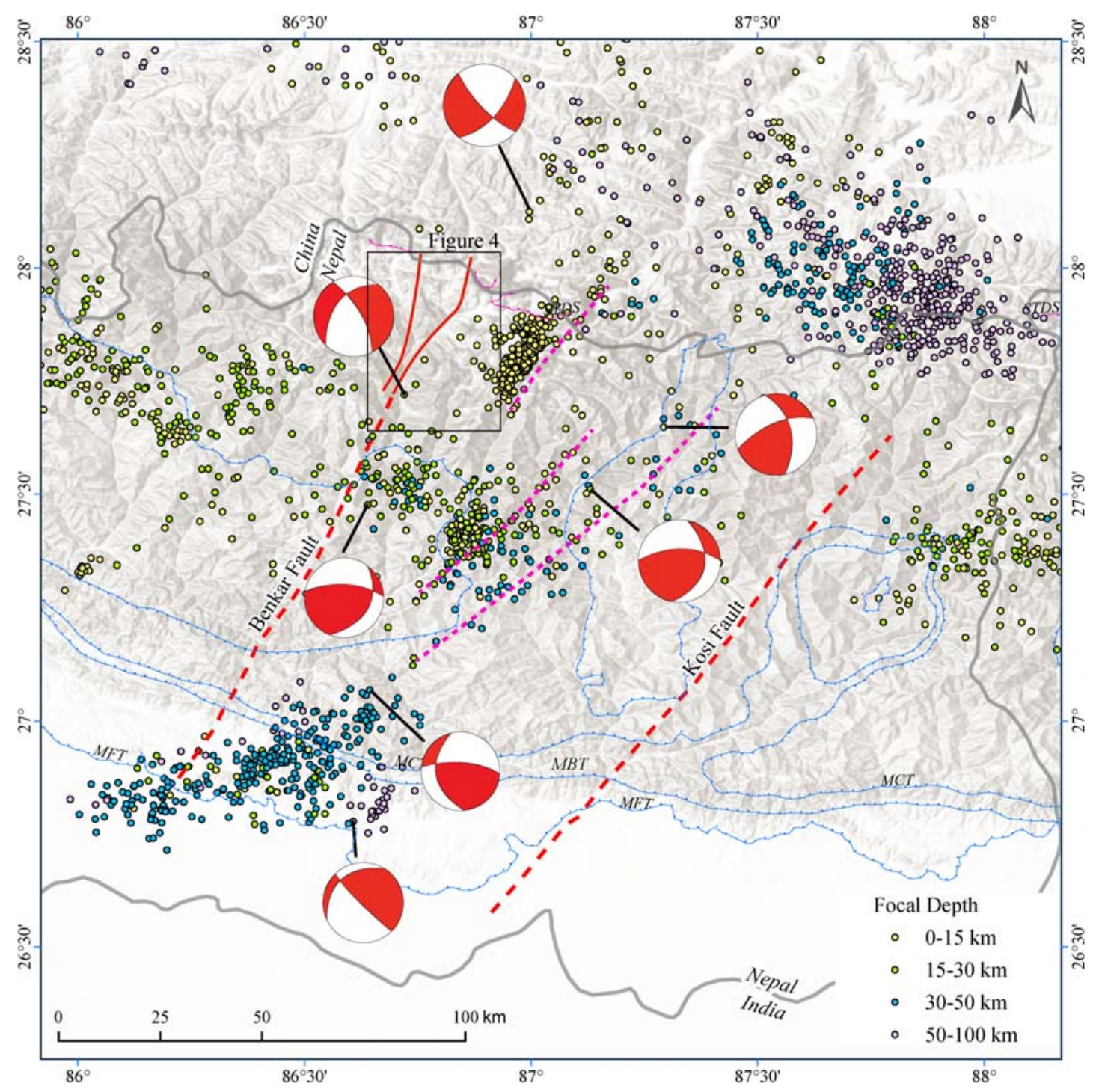

FIGURE 6 | Map of seismic events (magnitude > 1) in eastern Nepal during the time interval 1995-2003. Clusters of microseismicity align with the previously identified Benkar and Kosi Fault zones (red dashed lines), but there are other areas where the seismicity aligns along NE-oriented trends (pink dashed lines). Seismicity locations and depths from Rajaure et al. (2013) and focal mechanisms from Shanker et al. (2011). MBT: Main Boundary Thrust; MCT: Main Central Thrust; MFT: Main Frontal Thrust; STDS: South Tibetan Detachment System.

segments in the prism with alternating vergence of folds. In the offshore region of the Andes near the Peru-Chile border, seismic data from the Mw 8.4 Peru earthquake of 2001 showed that the main fault rupture propagated $\sim 70 \mathrm{~km}$ southward before stalling at a transverse surface (Robinson et al., 2006). After stalling for $30 \mathrm{~s}$ the rupture broke through the surface releasing significant energy in the process. That surface was interpreted as a fault that aligns with, and was likely caused by, a subducting fracture zone.

\section{CONCLUSION}

In summary, it is clear from geomorphologic, thermochronologic, structural, and geophysical data sets that tectonic processes along the length of the Himalaya have been segmented. Segment boundaries may be diffuse zones or may be discrete structures such as the cross faults. As an active collisional mountain belt, the Himalaya is a perfect place to try to understand the factors that control segmentation and to understand how these factors have evolved through time. Ultimately this understanding may help us to understand mountain building processes that were active in older collisional zones. Moving forward, there is a need for more data on the field expression of segment boundaries and for more data regarding the temporal development of these boundaries. Understanding the location of these boundaries and their role in limiting fault plane rupture and ameliorating MHT-related seismic hazard will help us to better understand the extent of the earthquake hazard in this active mountain range. 


\section{AUTHOR CONTRIBUTIONS}

$\mathrm{MH}, \mathrm{MMu}$, and $\mathrm{AGa}$ designed the review. $\mathrm{MMu}$ and $\mathrm{VS}$ contributed ideas and summaries of their work in the Indian Himalaya to the west and east of Nepal. MH, AGa, BG, and NS contributed summaries of their work on the Benkar Fault and the Khumbu region of Nepal. AGh and MMe contributed their analyses of seismic data from the Gorkha earthquake in Nepal. MH wrote the manuscript. BG drafted the map figures. $\mathrm{MMu}, \mathrm{AGa}, \mathrm{AGh}, \mathrm{VS}, \mathrm{BG}, \mathrm{NS}$, and MMe improved the manuscript through discussion and revisions. All authors contributed to the article and approved the submitted version.

\section{REFERENCES}

Ader, T., Avouac, J.-P., Liu-Zeng, J., Lyon-Caen, H., Bollinger, L., Galetzka, J., et al. (2012). Convergence rate across the Nepal Himalaya and interseismic coupling on the Main Himalayan Thrust: Implications for seismic hazard. J. Geophys. Res. 117:B04403. doi: 10.1029/2011JB009071

Adlakha, V., Patel, R. C., and Lal, N. (2013). Exhumation and its mechanisms: a review of exhumation studies in the Himalaya. J. Geol. Soc. India 81, 481-502. doi: 10.1007/s12594-013-0064-0

Agarwal, K., Singh, I., Sharma, M., Sharma, S., and Rajago-Palan, G. (2002). Extensional tectonic activity in the craonward parts (peripheral bulge) of the Ganga Plain foreland basin, India. Int. J. Earth Sci. 91, 897-905. doi: 10.1007/ s00531-002-0265-z

Ambraseys, N. N., and Douglas, J. (2004). Magnitude calibration of north Indian earthquakes. Geophys. J. Int. 159, 165-206. doi: 10.1111/j.1365-246x.2004. 02323.x

Arora, B. R., Gahalaut, V. K., and Kumar, N. (2012). Structural control on alongstrike variation in the seismicity of the northwest Himalaya. J. Asian Earth Sci. 57, 15-24. doi: 10.1016/j.jseaes.2012.06.001

Avouac, J. P. (2003). Mountain building, erosion and the seismic cycle in the Nepal Himalaya. Adv. Geophy. 46, 1-80. doi: 10.1016/S0065-2687(03

Beaumont, C., Jamieson, R. A., Nguyen, M. H., and Medvedev, S. (2004). Crustal channel flows: 1. Numerical models with applications to the tectonics of the Himalayan-Tibetan orogen. J. Geophys. Res. 109:B06406. doi: 10.1029/ 2003JB002809

Bhattacharyya, K., and Mitra, G. (2009). A new kinematic evolutionary model for the growth of a duplex-An example from the Rangit duplex. Sikkim Himalaya, India. Gondwana Res. 16, 697-715. doi: 10.1016/j.gr.2009.07.006

Bilham, R. (2004). Earthquakes in India and the Himalaya: tectonics, geodesy and history. Ann. Geophys. 47, 839-858.

Bilham, R. (2019). "'Himalayan earthquakes: a review of historical seismicity and early 21st century slip potential,"," in Himalayan Tectonics: a Modern Synthesis, eds P. J. Treloar and M. P. Searle (London: Geological Society of London Special Publication), 423-482. doi: 10.1144/sp483.16

Bilham, R., Gaur, V. K., and Molnar, P. (2001). Himalayan seismic hazard. Science 2001:293.

Bookhagen, B., and Burbank, D. W. (2006). Topography, relief, and TRMMderived rainfall variations along the Himalaya. Geophys. Res. Lett. 33:L08405. doi: 10.1029/2006GL026037

Burchfiel, B. C., Zhiliang, C., Hodges, K. V., Yuping, L., Royden, L. H., Changrong, D., et al. (1992). The South Tibetan Detachment System, Himalayan Orogen: Extension Contemporaneous With and Parallel to Shortening in a Collisional Mountain Belt. Geolog. Soc. Am. Special Paper 269, 1-41. doi: 10.1130/SPE 269-p1

Burrard, S. G. (1915). Origin of the Indo-Gangetic trough, commonly called Himalayan foredeep. Proc. R Soc. Lond. 91A, 220-238. doi: 10.1098/rspa.1915. 0014

Cannon, J. M., Murphy, M. A., and Taylor, M. (2018). Segmented strain accumulation in the High Himalaya expressed in river channel steepness. Geosphere 14, 1131-1149. doi: 10 .1130/GES01508.1 doi: 10.1130/ges01508.1

\section{FUNDING}

This work was largely a review article and was not specifically funded by any agency. We acknowledge student support from the Geological Society of America Student Grants.

\section{ACKNOWLEDGMENTS}

We thank the Geological Society of America, the Fulbright Foundation, the Nepal Geological Society, and the HimalayanKarakorum-Tibet workshops that connected us at various conferences and fellowship programs.

Carosi, R., Montomoli, C., Rubatto, D., and Visoná, D. (2010). Late Oligocene high-temperature shear zones in the core of the Higher Himalayan Crystallines (lower Dolpo, Western Nepal). Tectonics 2010:29. doi: 10.1029/2008TC002400

Catlos, E. J., Harrison, T. M., Manning, C. E., Grove, M., Rai, S. M., Hubbard, M. S., et al. (2002). Records of the evolution of the Himalayan orogen from in situ Th$\mathrm{Pb}$ ion microprobe dating of monazite: Eastern Nepal and western Garhwal. J. Asian Earth Sci. 20, 459-479. doi: 10.1016/s1367-9120(01)00039-6

Cattin, R., and Avouac, M. P. (2000). Modeling mountain building and the seismic cycle in the Himalaya of Nepal. J. Geophy. Res. 105 13:407.

Constenius, K., Esser, R. P., and Layer, P. W. (2003). "Extensional collapse of the Charleston-Nebo salient and its relationship to space-time variations in Cordilleran orogenic belt tectonism and continental stratigraphy," in Cenozoic Systems of the Rocky Mountain Region, eds R. G. Raynolds and R. M. Flores (Denver, CO: Rocky Mountani SEPM), 303-353.

Cottle, J. M., Larson, K. P., and Kellett, D. A. (2015). How does the mid-crust accommodate deformation in large, hot collisional orogens? A review of recent research in the Himalayan orogen. J. Struct. Geol. 78, 119-133. doi: 10.1016/j. jsg.2015.06.008

Coutand, I., Whipp, D. M. Jr., Grujic, D., Bernet, M., Fellin, G., Bookhagen, B., et al. (2014). Geometry and kinematics of the Main Himalayan Thrust and Neogene crustal exhumation in the Bhutanese Himalaya derived from inversion of multithermochronologic data. J. Geophys. Res. 119, 1446-1481. doi: 10.1002/ 2013JB010891

Dal Zilio, L., Hetényi, G., Hubbard, J., and Bollinger, L. (2021). Building the Himalay from tectonic to earthquake scales. Nat. Rev. Earth Env. 2021, 143-141. doi: 10.1038/s43017-021-00143-1

Dal Zilio, L., Jolivet, R., and van Dinther, Y. (2020). Segmentation of the Main Himalayan Thrust illuminated by Bayesian inference of interseismic coupling. Geophys. Res. Lett. 47:e2019GL086424. doi: 10.1029/2019GL086424

Dasgupta, S., Mukhopadhyay, M., and Nandy, D. R. (1987). Active transverse features in the central portion of the Himalaya. Tectonophysics 136, 255-264. doi: 10.1016/0040-1951(87)90028-x

Dasgupta, S., Pande, P., Ganguly, D., and Iqbal, Z. (2000). Seismotectonic Atlas of India and its Environs. Calcutta: Geological Survey of India, 1-87.

De La Torre, T. L., Monsalve, G., Sheehan, A. F., Sapkota, S., and Wu, F. (2007). Earthquake processes of the Himalayan collision zone in eastern Nepal and the southern Tibetan Plateau. Geophys. J. Int. 171, 718-738. doi: 10.1111/j.1365246x.2007.03537.x

DeCelles, P. G., Carrapa, B., Ojha, T. P., Gehrels, G. E., and Collins, D. (2020). Structural and thermal evolution of the Himalayan thrust belt in midwestern Nepal. Geolog. Soc. Am. Special Paper 547, 1-77. doi: 10.1130/2020.2547(01)

DeCelles, P. G., Gehrels, G. E., Quade, J., and Ojha, T. P. (1998). Eocene-early Miocene foreland basin development and the history of Himalayan thrusting, western and central Nepal. Tectonics 17, 741-765. doi: 10.1029/98tc02598

DeCelles, P. G., Kapp, P., Gehrels, G. E., and Ding, L. (2014). PaleoceneEocene foreland basin evolution in the Himalaya of southern Tibet and Nepal: Implications for the age of initial India-Asia collision. Tectonics 33, 824-849. doi: 10.1002/2014TC003522

DeCelles, P. G., Robinson, D. M., Quade, J., Ojha, T. P., Garzione, C. N., Copeland, P., et al. (2001). Stratigraphy, structure, and tectonic evolution of 
the Himalayan fold-thrust belt in western Nepal. Tectonics 20, 487-509. doi: 10.1029/2000TC001226

Deeken, A., Thiede, R., and Sobel, E. (2011). Exhumational variability within the Himalaya of northwest India. Earth Planetar. Sci. Lett. 305, 103-114. doi: 10.1016/j.epsl.2011.02.045

Diehl, T., Singer, J., Hetényi, G., Grujic, D., Clinton, J., Giardini, D., et al. (2017). Seismotectonics of Bhutan: Evidence for segmentation of the Eastern Himalayas and link to foreland deformation. Earth Planetar. Sci. Lett. 471, 54-65. doi: 10.1016/j.epsl.2017.04.038

Divyadarshini, A., and Singh, V. (2019). Investigating topographic metrics to decipher structural model and morphotectonic evolution of the Frontal Siwalik Ranges, Central Himalaya, Nepal. Geomorphology 337, 31-52. doi: 10.1016/j. geomorph.2019.03.028

Dowrick, D. J., and Rhoades, D. A. (2004). Relations between earthquake magnitude and fault rupture dimensions: how regionally variable are they? Bull. Seismolog. Soc. Am. 94, 776-788. doi: 10.1785/0120030151

Drukpa, D., Velasco, A. A., and Doser, D. (2006). Seismicity in the Kingdom of Bhutan (1937-2003): Evidence for crustal transcurrent deformation. J. Geophys. Res. 111:B06301. doi: 10.1029/2004JB003087

Dubey, A. K. (1997). Simultaneous development of noncylindrical folds, frontal ramps, and transfer faults in a compressional regime: experimental investigations of Himalayan Examples. Tectonics 16, 336-346. doi: 10.1029/ 96tc02231

Dubey, A. K., Mishra, R., and Bhakuni, S. S. (2001). Erratic shortening from balanced cross sections of the western Himalayan foreland basin causes and implications for basin evolution. J. Asian Earth Sci. 19, 765-777. doi: 10.1016/ s1367-9120(01)00010-4

Duncan, C., Masek, J., and Fielding, E. (2003). How steep are the Himalaya? Characteristics and implications of along-strike topographic variations. Geology 31, 75-78. doi: 10.1130/0091-76132003031<0075:HSATHC<2.0.CO;2

Duvall, M. J., Waldron, J. W. F., Godin, L., and Najman, Y. (2020). Active strike-slip faults and an outer frontal thrust in the Himalayan foreland basin. Proc. Natl. Acad. Sci. 117, 17615-17621. doi: 10.1073/pnas.2001979117

Elliott, J. R., Jolivet, R., Gonzalez, P. J., Avouac, J. P., Hollingsworth, J., Searle, M. P., et al. (2016). Himalayan megathrust geometry and relation to topography revealed by the Gorkha earthquake. Nat. Geosci. 9, 174-180. doi: 10.1038 /ngeo2623

Eugster, P., Thiede, R. C., Scherler, D., Stubner, K., Sobel, E. R., and Strecker, M. R. (2018). Segmentation of the Main Himalayan Thrust Revealed by LowTemperature Thermochronometry in the Western Indian Himalaya. Tectonics 37, 2710-2726. doi: 10.1029/2017TC004752

Gahalaut, V. K., and Arora, B. R. (2012). Segmentation of seismicity along the Himalayan Arc due to structural heterogeneities in the underthrusting Indian plan and overriding Himalayan wedge. Episodes 35:4. doi: 10.18814/epiiugs/ 2012/v3514/006

Gansser, A. (1964). Geology of the Himalayas. New York,NY: Wiley Interscience.

Godin, L., and Harris, L. B. (2014). Tracking basement cross-strike discontinuities in the Indian crust beneath the Himalayan orogen using gravity data relationship to upper crustal faults. Geophys. J. Int. 198, 198-215. doi: 10.1093/ gji/ggu131

Godin, L., Grujic, D., Law, R. D., and Searle, M. P. (2006). "Channel flow, ductile extrusion and exhumation in continental collision zones: An introduction," in Channel Flow, Ductile Extrusion and Exhumation in Continental Collision Zones, eds R. D. Law, M. P. Searle, and L. Godin (London: Geological Society London, Special Publication), 1-23. doi: 10.1144/gsl.sp.2006.268. 01.01

Godin, L., Soucy la Roche, R., Waffle, L., and Harris, L. B. (2018). "Influence of inherited Indian basement faults on the evolution of the Himalayan orogen," in Crustal Architecture and Evolution of the Himalaya-Karakoram-Tibet Orogen, eds R. Sharma, I. M. Villa, and S. Kumar (London: Geological Society of London Special Publications).

Goldfinger, C., Kulm, L. D., Yeats, R. S., McNeill, L., and Hummon, C. (1997). Oblique strike-slip faulting of the central Cascadia submarine forearc. J. Geophys. Res. 102, 8217-8243. doi: 10.1029/96jb02655

Graindorge, D., Klingelhoefer, F., Sibuiet, J. C., McNeill, L., Henstock, T., Dean, S., et al. (2008). Impact of lower plate structure on upper plate deformation at the NW Sumatran convergent margin from seafloor morphology. Earth Planetar. Sci. Lett. 275, 201-210. doi: 10.1016/j.epsl.2008.04.053
Greenwood, L. V., Argles, T. W., Parrish, R. R., Harris, N. B., and Warren, C. (2016). The geology and tectonics of central Bhutan. J. Geol. Soc. 173, 352-369.

Grujic, D., Hollister, L. S., and Parrish, R. P. (2002). Himalayan metamorphic sequence as an orogenic channel: Insight from Bhutan. Earth Planetar. Sci. Lett. 198, 177-191. doi: 10.1016S0012-821X(02)00482-X

Harvey, J. E., Burbank, D. W., and Bookhagen, B. (2015). Along-strike changes in Himalayan thrust geometry: Topographic and tectonic discontinuities in western Nepal. Lithosphere 7, 511-518. doi: 10.1130/L444.1

Hauck, M. L., Nelson, K. D., Brown, L. D., Wenjin, Z., and Ross, A. R. (1998). Crustal structure of the Himalayan orogen at $\sim 90^{\circ}$ east longitude from Project INDEPTH deep reflection profiles. Tectonics 17, 481-500. doi: 10.1029/ 98TC01314

Heim, A., and Gansser, A. (1939). Central Himalaya-Geological Observation of the Swiss Expedition, 1936. Switzerland: Société Helvetique Science Naturelle.

Hetényi, G., Cattin, R., Berthet, T., Le Moigne, N., Chophel, J., Lechmann, S., et al. (2016). Segmentation of the Himalayas as revealed by arc-parallel gravity anomalies. Sci. Rep. 6:33866. doi: 10.1038/srep33866

Hodges, K. V. (2000). Tectonics of the Himalaya and southern Tibet from two perspectives. Geol. Soc. Am. Bull. 112, 324-350. doi: 10.1130/0016-7606(2000) $112<324$ :tothas $>2.0$. co; 2

Hodges, K. V. (2006). "A synthesis of the Channel Flow-Extrusion hypothesis as developed for the Himalayan-Tibetan orogenic system," in Channel Flow, Ductile Extrusion and Exhumation in Continental Collision Zones, eds R. D. Law, M. P. Searle, and L. Godin (London: Geological Society, London, Special Publications), 71-90. doi: 10.1144/gsl.sp.2006.268.01.04

Hodges, K. V., Hurtado, J. M., and Whipple, K. X. (2001). Southwared extrusion of Tibetan crust and its effect on Himalayan tectonics. Tectonics 20, 799-809. doi: 10.1029/2001tc001281

Hodges, K. V., Parrish, R., Housh, T., Lux, D., Burchfiel, B. C., Royden, L., et al. (1992). Simultaneous Miocene extension and shortening in the Himalayan orogen. Science 258, 1466-1470. doi: 10.1126/science.258.5087.1466

Hossler, T., Bollinger, L., Sapkota, S. N., Lav, J., Gupta, R. M., and Kandel, T. P. (2016). Surface ruptures of large Himalayan earthquakes in western Nepal: Evidence along a reactivated strand of the Main Boundary thrust. Earth Planetar. Sci. Lett. 434, 187-196. doi: 10.1016/j.epsl.2015.11.042

Hoste-Colomer, R., Bollinger, L., Lyon-Caen, H., Burtin, A., and Adhikari, L. B. (2017). Lateral structure variations and transient swarm revealed by seismicity along the Main Himalayan Thrust north of Kathmandu. Tectonophysics 71, 107-116. doi: 10.1016/j.tecto.2016.10.004

Hubbard, J., Almeida, R., Foster, A., Sapkota, S. N., Burgi, P., and Tapponnier, P. (2016). Structural segmentation controlled the 2015 MW 7.8 Gorkha earthquake rupture in Nepal. Geology 44, 639-642. doi: 10.1130/g38077.1

Hubbard, M., and Harrison, T. M. (1989). 40Ar/39Ar age constraints on deformation and metamorphism in the Main Central Thrust zone and Tibetan Slab, eastern Nepal Himalaya. Tectonics 8, 865-880. doi: 10.1029/ tc008i004p00865

Hubbard, M., and Mancktelow, N. (1992). Lateral displacement during Neogene convergence in the Western and Central Alps. Geology 20, 943-946. doi: 10. 1130/0091-7613(1992)020<0943:Iddnci>2.3.co;2

Hubbard, M., Gajurel, A. P., Mukul, M., and Seifert, N. (2018). Cross faults and their role in Himalayan Structural Evolution in Procceeding of the Geological Society of America Abstracts with Programs. Indiana, USAs

Huyghe, P., Galy, A., Mugnier, J. L., and France-Lanord, C. (2001). Propagation of the thrust system and erosion in the Lesser Himalaya: Geochemical and sedimentological evidence. Geology 29, 1007-1010. doi: 10.1130/009176132001029<1007:POTTSA<2.0.CO;2

Jessup, M. J., Newell, D. L., Cottle, J. M., Berger, A. L., and Spotila, J. A. (2008). Orogen-parallel extension and exhumation enhanced by denudation in the trans-Himalayan Arun River gorge, Ama Drime Massif, Tibet-Nepal. Geology 36, 587-590. doi: 10.1130/g24722a.1

Johnson, M. R. W., and Harley, S. (2012). Orogenesis: the making of mountains. Cambridge, MA: Cambridge University Press.

Johnson, M. R. W., Oliver, G. J. H., Parrish, R. R., and Johnson, S. P. (2001). Synthrusting metamorphism, cooling, and erosion of the Himalayan Kathmandu Complex, Nepal. Tectonics 20, 394-415. doi: 10.1029/2001TC900005

Karplus, M. S., Pant, M., Sapkota, S. N., Nabelek, J., Valesco, A. A., Adhikari, L. B., et al. (2020). A Rapid response network to record aftershocks of the 2015 
Mw 7.8 Gorkha earthquake in Nepal. Seismolog. Res. Lett. 2020:0220190394. doi: $101.1758 / 0220190394$

Kellett, D. A., Cottle, J. M., and Larson, K. P. (2018). "The South Tibetan detachment system: History, advances, definition and future directions," in Himalayan Tectonics: A Modern Synthesis, eds P. J. Treloar and M. P. Searle (London: Geological Society, London, Special Publication), 377-400. doi: 10. $1144 / \mathrm{sp} 483.2$

Kimura, K. (1999). Diachronous Evolution of Sub-Himalayan Piggyback Basins. Island Arc 8. 1, 99-113. doi: 10.1046/j.1440-1738.1999.00224.x

Kohn, M. J. (2008). P-T-t data from central Nepal support critical taper and repudiate large-scale channel flow of the Greater Himalayan Sequence. Geol. Soc. Am. Bull. 120, 259-273. doi: 10.1130/B26252.1

Kohn, M. J. (2014). Himalayan metamorphism and its tectonic implications. Ann. Rev. Earth Planetar. Sci. 42, 381-419. doi: 10.1146/annurev-earth-060313055005

Larson, K. P. (2018). Refining the structural framework of the Khimti Khola region, east-central Nepal Himalaya, using quartz textures and c-axis fabrics. J. Struct. Geol. 107, 142-152. doi: 10.1016/j.jsg.2017.12.014

Larson, K. P., and Cottle, J. M. (2014). Midcrustal discontinuities and the assembly of the Himalayan midcrust. Tectonics 33, 718-740. doi: 10.1002/2013tc003452

Le Roux-Mallouf, R., Ferry, M., Cattin, R., Ritz, J. F., Drukpa, D., and Pelgay, P. (2020). A 2600-year-long paleoseismic record for the Himalayan Main Frontal Thrust (western Bhutan). Solid Earth 11, 2359-2375. doi: 10.5194/se-11-23592020

Long, S., McQuarrie, N., Tobgay, T., and Grujic, D. (2011). Geometry and crustal shortening of the Himalayan fold-thrust belt, eastern and central Bhutan. Geol. Soc. Am. Bull. 123, 1427-1447. doi: 10.1130/B30203.1

Maheo, G., Leloup, P. H., Valli, F., Lacassin, R., Arnaud, N., Paquette, J.-L., et al. (2007). Post $4 \mathrm{Ma}$ initiation of normal faulting in southern Tibet. Constraints from the Kung Co half graben. Earth Planetar. Sci. Lett. 256, 233-243. doi: 10.1016/j.epsl.2007.01.029

Mahoney, L., Hill, K., McLaren, S., and Hanani, A. (2017). Complex fold and thrust belt structural styles: examples from the Greater Juh area of the Papuan Fold and Thrust Belt, Papua New Guinea. J. Struct. Geol. 100, 98-119. doi: 10.1016/j.jsg.2017.05.010

Marechal, A., Mazzotti, S., Cattin, R., Cazes, G., Vernant, P., Drukpa, D., et al. (2016). Evidence of interseismic coupling variations along the Bhutan Himalayan arc from new GPS data. Geophys. Res. Lett. 43, 399-312. doi: 10. 1002/2016GL071163

Matin, A., and Mukul, M. (2010). Phases of deformation from cross-cutting structural relationships in external thrust sheets: insights from small-scale structures in the Ramgarh thrust sheet, Darjeeling Himalaya, West Bengal. Curr. Sci. 99, 1369-1377.

Matin, A., and Mukul, M. (2020). Himalayan cross faults affect thrust sheet geometry: An example from the Munsiari thrust sheet near the Gish Transverse fault zone, frontal Darjiling Himalaya, India. J. Asian Earth Sci. 199, 104400. doi: 10.1016/j.jseaes.2020.104400

McQuarrie, N., Robinson, D., Long, S., Tobgay, T., Grujic, D., Gehrels, G., et al. (2008). Preliminary stratigraphic and structural architectureof Bhutan: Implications for the along strike architecture of the Himalayan system. Earth Planetar Sci. Lett. 272, 105-117. doi: 10.1016/j epsl.2008.04.030

Meigs, A., Burbank, D. W., and Beck, R. A. (1995). Middle-late Miocene (>10 Ma) initiation of the Main Boundary thrust in the western Himalaya. Geology 23, 423-426. doi: 10.1130/0091-7613(1995)023<0423:mlmmfo > 2.3.co;2

Mendoza, M. M., Ghosh, A., Karplus, M. S., Klemperer, S. L., Sapkota, S. N., Adhikari, L. B., et al. (2019). Duplex in the Main Himalayan Thrust illuminated by aftershocks of the $2015 \mathrm{Mw} 7.8$ Gorkha earthquake. Nat. Geosci. 12, 10181022. doi: 10.1038/s41561-019-0474-8

Mendoza, M., Ghosh, A., and Rai, S. S. (2016). Dynamic triggering of small local earthquakes in the central Himalaya. Geophys. Res. Lett. 43:GL069969. doi: 10.1002/2016GL069969

Mitra, G., Bhattacharyya, K., and Mukul, M. (2010). The Lesser Himalayan Duplex in Sikkim: implications for variations in Himalayan shortening. J. Geolog. Soc. India 75, 276-288.

Monsalve, G., Sheehan, A., Schulte-Pelkum, V., Rajaure, S., Pandsy, M. R., and Wu, F. (2006). Seismicity and one-dimensional velocity structure of the Himalayan collision zone: earthquakes in the crust and upper mantle. J. Geophys. Res. 111:B10301. doi: 10.1029/2005JB004062
Montemagni, C., Montomoli, C., Iaccarino, S., Carosi, R., Jain, A. K., Massonne, H.-J., et al. (2019). "Dating protracted fault activities: microstructures, microchemistry and geochronology of the Vaikrita Thrust, Main Central Thrust zone, Garhwal Himalaya, NW India," in Crustal Architecture and Evolution of the Himalaya-Karakoram-Tibet Orogen, eds R. Sharma, I. M. Villa, and S. Kumar (London: Geological Society, London, Special Publications).

Mugnier, J. L., Jouanne, F., Bhattarai, R., Cortes-Aranda, J., Gajurel, A., Leturmy, P., et al. (2017). Segmentation of the Himalayan megathrust around the Gorkha earthquake (25 April 2015) in Nepal. J. Asian Earth Sci. 141, 236-252. doi: $10.1016 /$ j.jseaes.2017.01.015

Mugnier, J. L., Leturmy, P., Huyghe, P., and Chalaron, E. (1999b). The Siwaliks of western Nepal II. Mechanics of the thrust wedge. J. Asian Earth Sci. 17, 643-657. doi: 10.1016/s1367-9120(99)00039-5

Mugnier, J.-L., and Huyghe, P. (2006). The Ganges Basin geometry records a pre-15 Ma isostatic rebound of Himalaya. Geology 34, 445-448. doi: 10.1130/G22089.1

Mugnier, J.-L., Leturmy, P., Mascle, G., Huyghe, P., Chalaron, E., Vidal, G., et al. (1999a). The Siwaliks of western Nepal 1: Geometry and kinematics. J. Asian Earth Sci. 17, 629-642. doi: 10.1016/S1367-9120(99)00038-3

Mukul, M. (2000). The geometry and kinematics of the Main Boundary Thrust and related neotectonics in the Darjiling Himalayan fold-and-thrust belt, West Bengal, India. J. Struct. Geol. 22, 1261-1283. doi: 10.1016/s0191-8141(00) 00032-8

Mukul, M. (2010). First-order kinematics of wedge-scale active Himalayan deformation: insights from Darjiling-Sikkim-Tibet (DaSiT) wedge. J. Asian Earth Sci. 39, 645-657. doi: 10.1016/j.jseaes.2010.04.029

Mukul, M., Jade, S., and Matin, A. (2009). Active deformation in the DarjilingSikkim Himalaya based on 2000-2004 Geodetic Global Positioning System measurements. GPS Geodesy 2009, 1-28.

Mukul, M., Jade, S., Ansari, K., Matin, A., and Joshi, V. (2018). Structural insights from geodetic Global Positioning System measurements in the Darjiling-Sikkim Himalaya. J. Struct. Geol. 114, 346-356. doi: 10.1016/j.jsg.2018.03.007

Mukul, M., Jaiswal, M., and Singhvi, A. K. (2007). Timing of out-of-sequence active deformation in the frontal Himalayan wedge: Insights from the Darjiling sub-Himalaya. India. Geology 35, 999-1002. doi: 10.1130/G23869A.1

Nabelek, J., Hetényi, G., Vergne, J., Sapkota, S., Kafle, B., Jiang, M., et al. (2009). Underplating in the Himalaya-Tibet collision zone revealed by the Hi-CL IMB experiment. Science 325, 1371-1374. doi: 10.1126/science.1167719

Nakata, T. (1972). Geomorphic history and crustal movement of the foot-hills of the Himalayas. Sci. Rep. Tohoku Univ. 22, 39-177.

Ni, J., and Barazangi, M. (1984). Seismotectonics of the Himalayan Collision Zone: geometry of the underthrusting Indian Plate beneath the Himalaya. J. Geophys. Res. 89, 1147-1163. doi: 10.1029/jb089ib02p01147

Ojha, T. P., Butler, R. F., Quade, J., DeCelles, P. G., Richards, D., and Upreti, B. N. (2000). Magnetic polarity stratigraphy of the Neogene Siwalik Group at Khutia Khola, far western Nepal. Geol. Soc. Am. Bull. 112, 424-434. doi: 10.1130/0016-76062000112<424:MPSOTN $<2.0 . C O ; 2$

Oldham, R. D. (1917). Structure of the Himalayas and Indo-Gangetic plains. Memoir Geolog. Survey India 1917:156.

Orme, D. A., Reiners, P. W., Hourigan, J. K., and Carrapa, B. (2015). Effects of inherited cores and magmatic overgrowths on zircon (U-Th)/He ages from Greater Himalayan sequence rocks, Mt. Everest region, Tibet. Geochem. Geophys. Geosyst. 16, 2499-2507. doi: 10.1002/2015GC005818

Pandey, M. R., Tandukar, R. P., Avouac, J. P., Lavé, J., and Massot, J. P. (1995). Interseismic strain accumulation on the Himalayan crustal ramp (Nepal). Geophys. Res. Lett. 22, 751-754. doi: 10.1029/94gl02971

Pandey, M. R., Tandukar, R. P., Avouac, J. P., Vergne, J., Heritier, and Th. (1999). Seismotectonics of the Nepal Himalaya from a local seismic network. J. Asian Earth Sci. 17, 703-712. doi: 10.1016/s1367-9120(99)00034-6

Paul, H., Mitra, S., Bhattacharya, S. N., and Suresh, G. (2015). Active transverse faulting within underthrust Indian crust beneath the Sikkim Himalaya. Geophys. J. Int. 201, 1070-1081. doi: 10.1093/gji/ggv058

Powers, P. M., Lillie, R. J., and Yeats, R. S. (1998). Structure and shortening of the Kangra and Dehra Dun reentrants, Sub-Himalaya, India. Geol. Soc. Am. Bull. 110, 1010-1027. doi: 10.1130/0016-760619 98110

Raiverman, V., Kunte, S. V., and Mukherjea, A. (1983). Basin geometry, Cenozoic sedimentation and hydrocarbon in northwestern Himalaya and Indo-Gangetic plains. Petrol. Geol. Asia J. 6, 67-92. doi: 10.1016/0040-1951(80)90136-5 
Rajaure, S., Sapkota, S. N., Adhikari, L. B., Koirala, B., Bhattarai, M., Tiwari, D. R., et al. (2013). Double difference relocation of local earthquakes in the Nepal Himalaya. J. Nepal Geolog. Soc. 46, 133-142.

Rajendra Prasad, B., Klemperer, S. L., Vijaya Rao, V., Tewari, H. C., and Khare, P. (2011). Crustal structure beneath the Sub-Himalayan fold-thrust belt, Kangra recess, northwest India, from seismic reflection profiling: Implications for late Paleoproterozoic orogenesis and modern earthquake hazard. Earth Planetar. Sci. Lett. 308, 218-228. doi: 10.1016/j.epsl.2011.05.052

Rao, M. B. R. (1973). The subsurface geology of the Indo-Gangetic plains. J. Geolog. Soc. India 14, 217-242.

Robert, X., van der Beek, P., Braun, J., Perry, C., and Mugnier, J.-L. (2011). Control of detachment geometry on lateral variations in exhumation rates in the Himalaya: Insights from low-temperature thermochronology and numerical modeling. J. Geophys. Res. 116:B05202. doi: 10.1029/2010JB007893

Robinson, D. M., DeCelles, P. G., Patchett, P. J., and Garzione, C. N. (2001). The kinematic history of the Nepalese Himalaya interpreted from Nd isotopes. Earth Planetary Sci. Lett. 192, 507-521. doi: 10.1016/S0012-821X(01)00451-4

Robinson, D. P., Das, S., and Watts, A. B. (2006). Earthquake Rupture Stalled by a Subducting Fracture Zone. Science 312, 1203-1205. doi: 10.1126/science. 1125771

Sahoo, P. K., Kumar, S., and Singh, R. P. (2000). Neotectonic study of Ganga and Yamuna tear faults, NW Himalaya, using remote sensing and GIS. Int. J. Remote Sens. 21, 499-518. doi: 10.1080/014311600210713

Sastri, V. V., Bhandari, L. L., Raju, A. T. R., and Datta, A. K. (1971). Tectonic framework and subsurface stratigraphy of the Ganga Basin. J. Geol. Soc. India $12,222-233$.

Searle, M. P., and Treloar, P. J. (2019). "Introduction to Himalayan tectonics: a modern synthesis," in Himalayan Tectonics: A Modern Synthesis, eds P. J. Treloar and M. P. Searle (London: Geological Society of London Special Publications), 1-17. doi: 10.1144/sp483-2019-20

Searle, M. P., Law, R. D., Godin, L., Larson, K. P., Streule, M. J., Cottle, J. M., et al. (2008). Defining the Himalayan Main Central Thrust in Nepal. J. Geol. Soc. Lond. 165, 523-534. doi: 10.1144/0016-76492007-081

Searle, M. P., Simpson, R. L., Law, R. D., Parrish, R. R., and Waters, D. J. (2003). The structural geometry, metamorphic and magmatic evolution of the Everest massif, High Himalaya of Nepal-South Tibet. J. Geol. Soc. 160, 345-366. doi: 10.1144/0016-764902-126

Sears, J. W. (2016). "Template for the Cordilleran magmatic arc and its detached carapace, Idaho and Montana," in Belt Basin: Window to Mesoproterozoic Earth, ed. J. S. MacLean (Boulder, CO: Geological Society of America), 365-384. doi: 10.1130/2016.2522(14)

Seifert, N. (2019). Structural analysis of the Benkar Fault Zone, a cross structure in the higher Himalaya of the Khumbu Region, eastern Nepal. Bozeman, MT: Montana State University.

Seifert, N., Hubbard, M. S., Gajurel, A. P., and Shaw, C. A. (2019). "Structural analysis of the Benkar Fault zone, a cross structure in the Higher Himalaya of the Khumbu region, eastern Nepal," in 34th Himalayan-Karakorum-Tibet Workshop, eds A. Laskowski, D. Orme, M. Hubbard, D. Lageson, and K. Thomson (Bozeman, MT: Montana State University).

Selverstone, J. (1988). Evidence for east-west crustal extension in the eastern alps: implications for the unroofing history of the Tauern Window. Tectonics 7 , 87-105. doi: 10.1029/tc007i001p00087

Shanker, D., Paudyal, H., and Singh, H. N. (2011). Discourse on seismotectonics of Nepal Himalaya and vicinity. Geosciences 1, 1-15. doi: 10.5923/j.geo.20110 101.01

Silver, C. R. P., Murphy, M. A., Taylor, M. H., Gosse, J., and Baltz, T. (2015). Neotectonics of the Western Nepal Fault System: Implications for Himalayan strain partitioning. Tectonics 34, 2494-2513. doi: 10.1002/2014TC003730

Soucy La Roche, R., and Godin, L. (2019). Inherited cross-strike faults and Oligocene-early Miocene segmentation of the Main Himalayan Thrust, West Nepal. J. Geophys. Res. Solid Earth 124, 7429-7444. doi: 10.1029/2019JB017467

Soucy La Roche, R., Godin, L., Cottle, J. M., and Kellett, D. A. (2016). Direct shear fabric dating constrains early Oligocene onset of the South Tibetan detachment in the western Nepal Himalaya. Geology 44, 403-406. doi: 10.1130/G37754.1

Soucy La Roche, R., Godin, L., Cottle, J. M., and Kellett, D. A. (2018). Preservation of the early evolution of the Himalayan middle crust in foreland klippen: insights from the Karnali klippe, west Nepal. Tectonics 37, 1161-1193. doi: $10.1002 / 2017$ TC004847
Soucy La Roche, R., Godin, L., Cottle, J. M., and Kellett, D. A. (2019). Tectonometamorphic evolusion of the tip of the Himalayan metamorphic core in the Jajarkot klippe, west Nepal. J. Metam. Geol. 37, 239-269. doi: 10.1111/ jmg. 12459

Srivastava, P., and Mitra, G. (1994). Thrust geometries and deep structure of the outer and lesser Himalaya, Kumaon and Garhwal (India): Implication for evolution of the Himalayan fold-and-thrust belt. Tectonics 13, 89-109. doi: 10.1029/93TC01130

Srivastava, V., and Mukul, M. (2020). Cataclastic strain from external thrust sheets in fold-thrust belts: Insights from the frontal Indian Himalaya. J. Asian Earth Sci. 188, G37754.1.

Srivastava, V., Mukul, M., Barnes, J. B., and Mukul, M. (2018). Geometry and kinematics of Main Frontal thrust-related fault propagation folding in the Mohand Range, northwest Himalaya. J. Struct. Geol. 115, 1-18. doi: 10.1016/ j.jsg.2018.06.022

Srivastava, V., Mukul, Malay, and Barnes, J. B. (2016). Main Frontal Thrust deformation and topographic growth of the Mohand Range, northwest Himalaya. J. Struct. Geol. 93, 131-148. doi: 10.1016/j.jsg.2016.10.009

Srivastava, V., Mukul, Manas, Mukul, and Malay. (2017). Quaternary deformation in the Gorubathan recess: Insights on the structural and landscape evolution in the frontal Darjiling Himalaya. Q. Int. 462, 138-161. doi: 10.1016/j.quaint.2017. 05.004

Stearns, R. G. (1955). Low-angle overthrusting in the central Cumberland Plateau, Tennessee. Bull. Geol. Soc. Am. 66, 615-628. doi: 10.1130/0016-7606(1955) 66[615:loitcc]2.0.co;2

Stevens, V. L., and Avouac, J. P. (2015). Interseismic coupling on the main Himalayan thrust. Geophys. Res. Lett. 42, 5828-5837. doi: 10.1002/ 2015GL064845

Stevens, V. L., and Avouac, J. P. (2016). Millenary Mw>9.0 earthquakes required by geodetic strain in the Himalaya. Geophys. Res. Lett. 43, 1118-1123. doi: 10.1002/2015GL067336

Suess, E. (1904). The Face of the Earth (Das Antlitz der Erde). United Kingdom: Clarendon Press, Oxford, 604.

Szulc, A. G., Najman, Y., Sinclair, H. D., Pringle, M., Bickle, M., Chapman, H., et al. (2006). Tectonic evolution of the Himalaya constrained by detrital 40Ar-39Ar, Sm-Nd and petrographic data from the Siwalik foreland basin succession, SW Nepal. Basin Res. 18, 375-391. doi: 10.1111/j.1365-2117.2006. 00307.x

Thakur, V. C. (1998). Structure of the Chamba nappe and position of the Main Central Thrust in Kashmir Himalaya. J. Asian Earth Sci. 16, 269-282. doi: 10.1016/s0743-9547(98)00011-7

Thakur, V. C., Jayangondaperumal, R., and Joevivek, V. (2019). "Seismotectonics of central and NW Himalaya: plate boundary-wedge thrust earthquakes in thinand thick-skinned tectonic framework," in Crustal Architecture and Evolution of the Himalaya-Karakoram Tibet Orogen, eds R. Sharma, I. M. Villa, and S. Kumar (London: Geological Society of London), doi: 10.1144/SP481.8

Thakur, V. C., Joshi, M., Sahoo, D., Suresh, N., Jayangondapermal, R., and Singh, A. (2014). Partitioning of convergence in Northwest Sub-Himalaya: Estimation of late Quaternary uplift and convergence rates across the Kangra re-entrant, North India. Int. J. Earth Sci. 103, 1037-1056. doi: 10.1007/s00531-014-1 016-7

Thiede, R., Robert, X., Stübner, K., Dey, S., and Faruhn, J. (2017). Sustained out-ofsequence shortening along a tectonically active segment of the Main Boundary thrust: The Dhauladhar Range in the northwestern Himalaya. Lithosphere 9, 717-725. doi: 10.1130/L630.1

Upreti, B. N., Rai, S. M., Sakai, H., Koirala, D. R., and Takigami, Y. (2003). Early Proterozoic granite of the Taplejung Window, far eastern Lesser Nepal Himalaya. J. Nepal Geol. Soc. 28, 9-18.

Valdiya, K. S. (1976). Himalayan transverse faults and folds and their parallelism with subsurface structures of North Indian plains. Tectonophysics 32, 353-386. doi: 10.1016/0040-1951(76)90069-x

van der Beek, P., Litty, C., Baudin, M., Mercier, J., Robert, X., and Hardwick, E. (2016). Contrasting tectonically driven exhumation and incision patterns, western versus central Nepal Himalaya. Geology 44, 327-330. doi: 10.1130/ G37579.1

Veevers, J. J., and Tewari, R. C. (1995). Gondwana master basin of peninsular India between Tethys and the interior of the Gondwanaland province of Pangea. Boulder: Geological Society of America, Memoirs. 187. 
Virdi, N. S. (1979). On the geodynamic significance of mega-lineaments in the outer and lesser regions of western Himalaya. Himal. Geol. 9, 79-99.

Webb, A. A. G., Guo, H., Clift, P. D., Husson, L., Müller, T., Costantino, D., et al. (2017). The Himalaya in 3D: Slab dynamics controlled mountain building and monsoon intensification. Geosphere 9, 637-651. doi: 10.1130/L636.1

Weinberg, R. F. (2016). Himalayan leucogranites and migmatites: nature, timing and duration of anatexis. J. Metamorp. Geol. 34, 821-843. doi: 10.111/jmg. 12204

Wesnousky, S. G., Kumahara, Y., Chamlagain, D., and Neupane, P. J. (2019). Large Himalayan Frontal Thrust paleoearthquake at Khayarmara in eastern Nepal. J. Asian Earth Sci. 174, 346-351. doi: 10.1016/j.jseaes.2019.01.008

Yeats, R. S., and Lillie, R. J. (1991). Contemporary tectonics of the Himalayan frontal fault system: folds, blind thrusts and the 1905 Kangra earthquake. J. Struct. Geol. 13, 215-225. doi: 10.1016/0191-8141(91)9 0068-t

Yin, A. (2006). Cenozoic tectonic evolution of the Himalayan orogen as constrained by along-strike variation of structural geometry, exhumation history, and foreland sedimentation. Earth Sci. Rev. 76, 1-131. doi: 10.1016/j. earscirev.2005.05.004
Yin, A., and Taylor, M. (2011). Mechanics of V-shaped conjugate strikeslip faults and the corresponding continuum mode of continental deformation. Geol. Soc. Am. Bull. 123, 1798-1821. doi: 10.1130/B3 0159.1

Zhao, W., Nelson, K. D., and Project Indepth Team. (1993). Deep seismic reflection evidence for continental underthrusting beneath southern Tibet. Nat. Geosci. 366, 557-559. doi: 10.1038/366557a0

Conflict of Interest: The authors declare that the research was conducted in the absence of any commercial or financial relationships that could be construed as a potential conflict of interest.

Copyright (C) 2021 Hubbard, Mukul, Gajurel, Ghosh, Srivastava, Giri, Seifert and Mendoza. This is an open-access article distributed under the terms of the Creative Commons Attribution License (CC BY). The use, distribution or reproduction in other forums is permitted, provided the original author(s) and the copyright owner(s) are credited and that the original publication in this journal is cited, in accordance with accepted academic practice. No use, distribution or reproduction is permitted which does not comply with these terms. 